I NTER NATIONAL MONETARY FUND

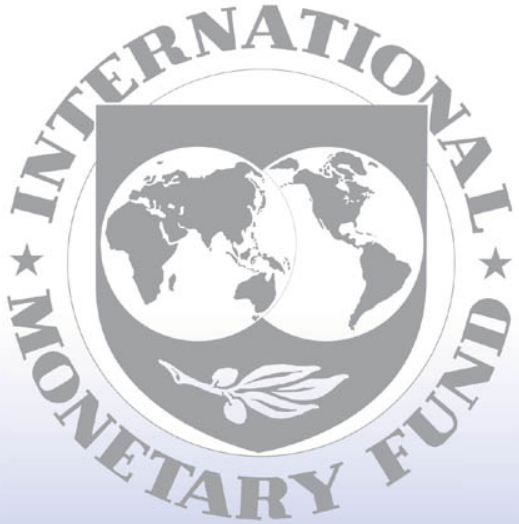

Staff

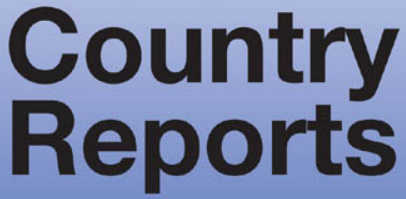




\title{
Belize: 2001 Article IV Consultation-Staff Report; Public Information Notice on the Executive Board Discussion; and Statement by the Authorities of Belize
}

Under Article IV of the IMF's Articles of Agrecment, the IMF holds bilateral discussions with members, usually every year. In the context of the 2001 Article IV consultation with Belize, the following documents have been released and are included in this package:

- the staff report for the 2001 Article IV consultation, prepared by a staff team of the IMF, following discussions that ended on May 2, 2001, with the officials of Belize on economic developments and policies. Based on information available at the time of these discussions, the staff report was completed on June 20, 2001. The views expressed in the staff report are those of the staff team and do not necessarily reflect the views of the Executive Board of the IMF.

- the Public Information Notice (PIN), which summarizes the views of the Executive Board as expressed during its July 9, 2001, discussion of the staff report that concluded the Article IV consultation.

- a statement by the authorities of Belize.

The docurnent listed below has been or will be separately released.

Selected Issues and Statistical Appendix

The policy of publication of staff reports and other documents by the IMF allows for the deletion of market-sensitive information.

To assist the IMF in evaluating the publication policy, reader comments are invited and may be sent by e-mail to Publicationpolicy@imf.org.

\author{
Copies of this report are available to the public from \\ International Monetary Fund - Publication Services \\ 700 19th Street, N.W. • Washington, D.C. 20431 \\ Telephone: (202) 6237430 - Telefax: (202) 6237201 \\ E-mail: publications@imf.org • Internet: http://www.imf.org \\ Price: $\$ 15.00$ a copy
}

\section{International Monetary Fund \\ Washington, D.C.}




\section{INTERNATIONAL MONETARY FUND}

\section{BELIZE \\ Staff Report for the 2001 Article IV Consultation \\ Prepared by the Staff Representatives for the \\ 2001 Consultation with Belize \\ Approved by Claudio M. Loser and Jesús Seade}

June 20, 2001

Contents

Page

Executive Summary

3

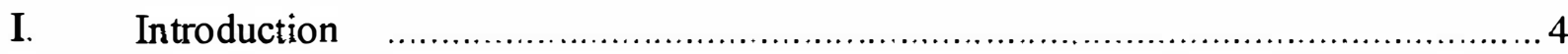

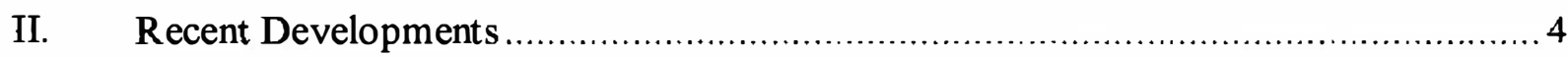

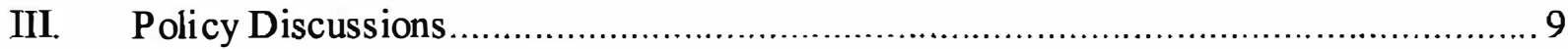

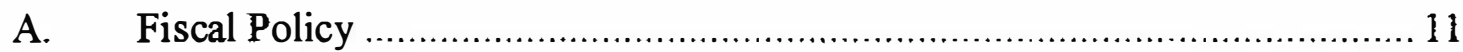

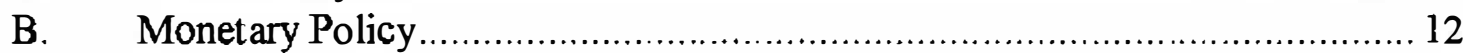

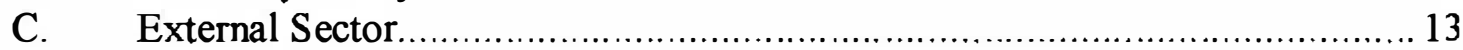

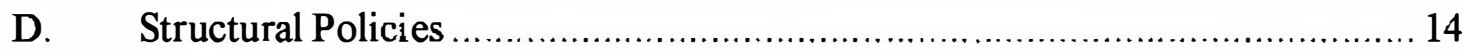

E. Statistical Issues $\ldots \ldots \ldots \ldots \ldots \ldots \ldots \ldots \ldots \ldots \ldots \ldots \ldots \ldots \ldots \ldots \ldots \ldots \ldots 16$

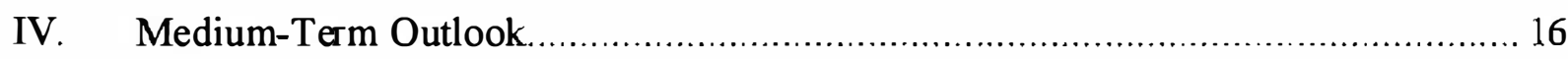

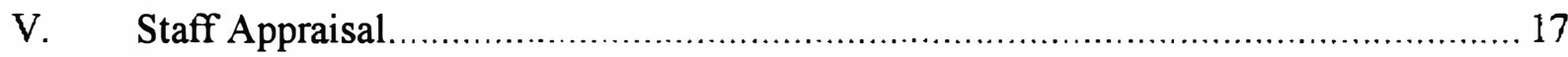

Text Boxes

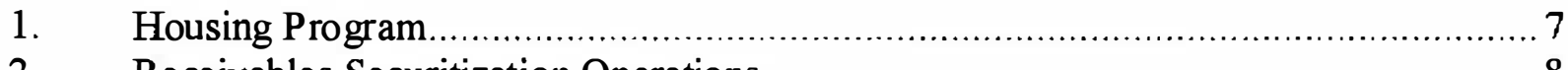

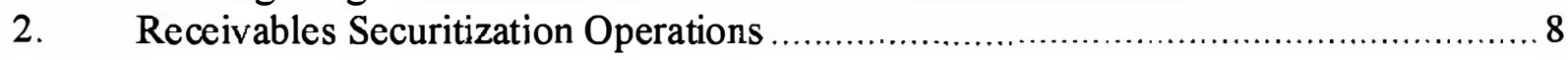

$\underline{\text { Figures }}$

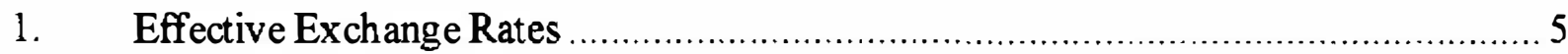

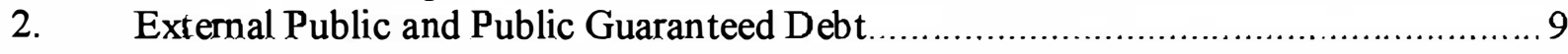

CInternational Monetary Fund. Not for Redistribution 
Tables

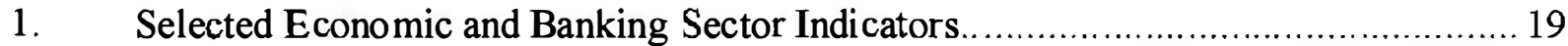

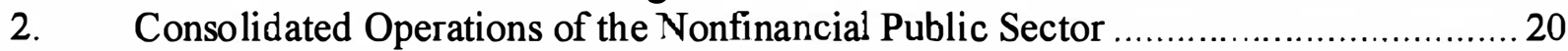

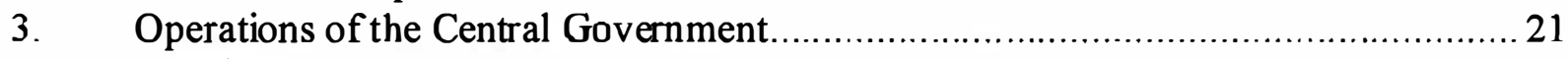

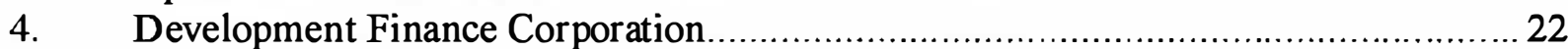

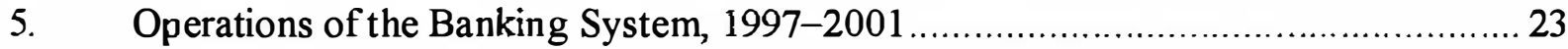

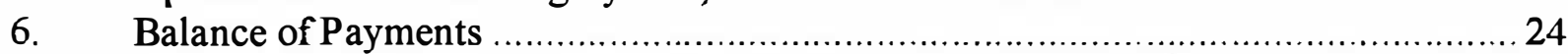

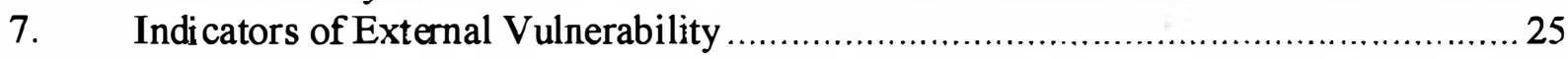

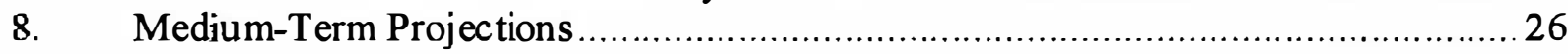

Appendices

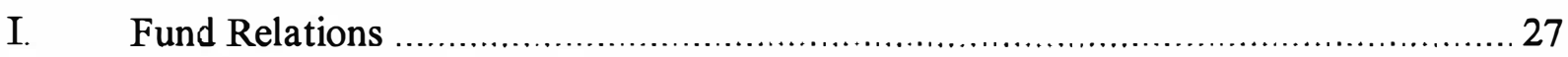

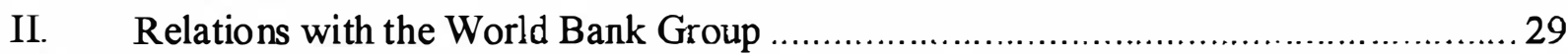

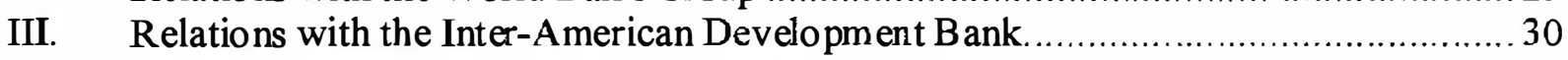

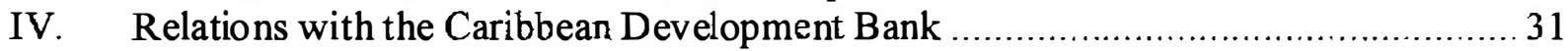

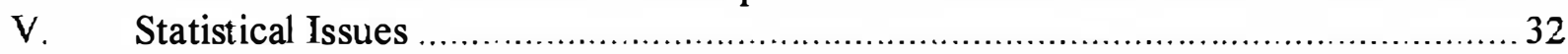




\section{EXECUTIVE SUMMARY}

Real GDP growth is estimated to have increased sharply to 10.4 percent in 2000 , while consumer prices rose by 1 percent. The nonfinancial public sector deficit widened to 9.7 percent of GDP in FY 2000/01 from 8.2 percent in FY 1999/2000 (fiscal year begins April 1) in part due to hurricane reconstruction efforts, and was financed by privatization receipts and external borrowing, on commercial terms and to a small extent from multilateral sources. The state-owned Development Finance Corporation (DFC) expanded its lending operations by 10 percent of GDP, financed through receivables securitization and external borrowing. As a result, the public and publicly guaranteed external debt increased from 48 percent of GDP at end-1999 to 67 percent at end-2000. The central government's external debt rose from 27 percent of GDP to 39 percent of GDP during the same period. The expansionary fiscal stance, combined with the liquidity injection through the DFC operations, increased the liquidity overhang in the economy, and created pressures in foreign exchange markets.

The authorities' economic policy has sought to achieve strong economic growth mainly through low taxes, large public investment, and the provision of credit to the private sector through the DFC. The authorities expect the high rate of economic growth, improved tax administration and expenditure restraint to reduce the public sector deficit and facilitate external public debt service.

In the context of a medium-term scenario that was developed to underscore the need to reduce the fiscal imbalance and the excess liquidity, the mission urged the authorities to implement measures to achieve such a reduction by prioritizing public investment, increasing revenue collection by about 3 percent of GDP, and refraining from any further commercial borrowing. The mission also emphasized the urgent need to review DFC operations in light of its deteriorating loan portfolio, and pointed to the need to improve supervision of onshore and offshore financial institutions.

The authorities agreed that a reduction in the fiscal deficit in line with the medium-term scenario proposed by the staff was necessary, but did not envisage the need for new revenue measures and attached particular importance to the continuation of the lending activities of the DFC, albeit at a reduced rate of growth. However, in view of existing programs, the staff remained concerned about the feasibility of containing spending within the parameters of the medium-term scenario. The authorities intend to proceed with an audit of the DFC and subject it to banking supervision, and in this regard welcomed the offer of technical assistance from MAE. They also requested further technical assistance to develop quarterly balance of payments and national accounts data. 


\section{INTRODUCTION}

1. A mission visited Belize in the period April 16-May 2, 2001 to conduct the discussions for the 2001 Article IV consultation. ${ }^{1}$ It met with the Minister of the Budget, the Governor of the Central Bank of Belize (CBB), senior government officials, and representatives of the private sector. Belize accepted the obligations of Article VIII in 1983, and its last arrangement with the Fund ended in $1986 .{ }^{2}$

2. At the conclusion of the 2000 Article IV consultation on May 19, 2000 (SM/00/83), Executive Directors expressed concern about the sustainability of the authorities' fiscal policy. They noted that the privatization process would come to an end in one or two years, leaving a sizable fiscal gap. In this regard, Directors encouraged the authorities to base their medium-term fiscal projections on cautious assumptions about real GDP growth, and to aim for a much stronger public savings position and a reduction of the public investment program. Directors urged the authorities to strengthen their banking supervision capacity and to take advantage of the technical assistance offered by the Fund.

\section{RECENT DEVELOPMENTS}

3. The authorities' economic policy seeks to sustain high economic growth, mainly through low taxes, large public investment, and the provision of credit to the private sector through the state-owned Development Finance Corporation (DFC). The public investment program is focused on low-income housing and roads, while infrastructure investment, public-private cofinancing schemes, and tax concessions are the main instruments used to attract private investment in tourism, shrimp farming, and other primary exports. The authorities expect that the strong economic growth will generate sufficient fiscal resources, which combined with expenditure restraint and improved tax administration would reduce the public sector deficit and help service the rapidly accumulating external debt. At the same time, they remain firmly committed to the exchange rate peg, unchanged at BZ\$2 per US\$1 since 1976 , to help keep inflation low and stable.

4. Real GDP growth is estimated to have increased from 6.5 percent in 1999 to 10.4 percent in 2000 (Table 1), in part because of the reconstruction work in the aftermath of

${ }^{1}$ The mission consisted of Messrs. Fritz-Krockow (Head), Breuer, Gil-Diaz, Vesperoni, and Ms. Zermeño (all WHD), and Mr. Kandall (Caribbean Development Bank (CDB)).

Mr. Bernes, Executive Director, participated in the policy discussions.

${ }^{2}$ Relations with the Fund, the World Bank, the Inter-American Development Bank, and the CDB are presented in Appendices I-IV, respectively. 
hurricane Keith, which struck Belize during September 30-October 1, 2000. ${ }^{3}$ The hurricane damaged tourist facilities on the coast and sugar cane and rice fields, and caused extensive damage to roads and bridges in the north of the country. Growth was also spurred by new investment projects that came on-stream in the agriculture and fisheries sectors, and by residential construction, which benefited from ample government incentives and financing. ${ }^{4}$ National savings declined from 18.4 percent of GDP in 1999 to 15.5 percent of GDP in 2000, reflecting a deterioration in both public and private savings, while investment rose from 27.5 percent of GDP in 1999 to 31.6 percent of GDP. Consumer prices increased by 1 percent during the year after three years of moderate deflation. Wage pressures have been moderate as a result of immigration from neighboring countries. Price increases were mainly concentrated in nontradable goods, like medical care, transportation, and communication. The Belize dollar appreciated in real effective terms by about 4 percent from end-1998 to end-2000, but has shown relatively little variation over the course of the past decade (Figure 1).

Figure 1. Effective Exchange Rates

(Indices, 1990=100)

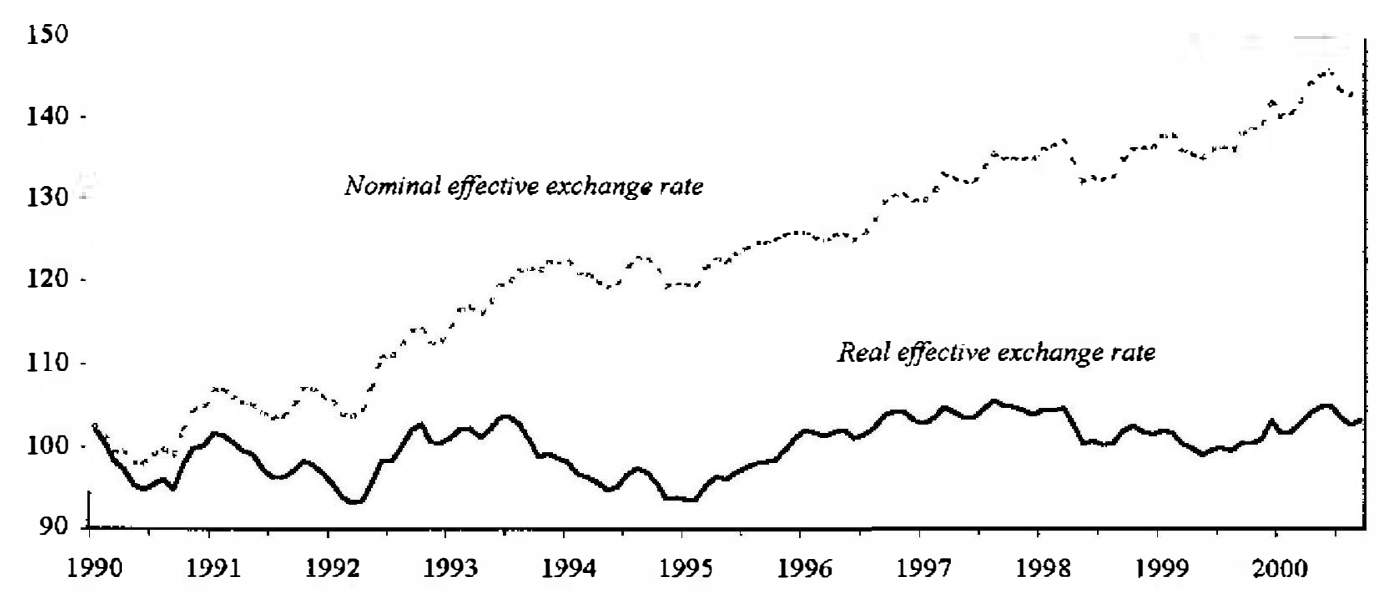

${ }^{3}$ Economic growth is somewhat overestimated in 2000 (around 1-2 percentage points) due to the use of an outdated estimation methodology based on a 1984 industrial survey. An updated estimation methodology will be used for 2001.

${ }^{4}$ See the companion paper "Selected Issues and Statistical Appendix" for a comparison of the growth rebound in 1999-2000 with the high-growth period during 1987-90. 
5. The nonfinancial public sector deficit increased from 8.2 percent of GDP in FY 1999/2000 to 9.7 percent of GDP in FY 2000/01 (Table 2). Current revenue contracted from 23.4 percent of GDP to 22.4 percent in FY 2000/01 due to a lack of tax buoyancy, in part reflecting increased tax exemptions for new activities, e.g., shrimp farming. Expenditure increased from 33.6 percent of GDP in FY 1999/2000 to 34.4 percent of GDP, as capital outlays increased from 13.0 percent of GDP in FY 1999/2000 to 15.5 percent of GDP. The capital expenditure outlays include 3.0 percent of GDP related to hurricane reconstruction efforts after hurricane Keith struck Belize in end-September 2000 (Table 3). At the same time, current expenditure contracted when measured in relation to GDP from 20.6 percent to 18.9 percent in FY 2000/01 as economic growth accelerated. ${ }^{5}$ During FY 2000/01, the government completed the sale of the Water Authority. After privatization receipts of 3.2 percent of GDP, the public sector net borrowing requirement stood at 6.4 percent of GDP. After external borrowing of 12.3 percent of GDP, nearly all on commercial terms, ${ }^{6}$ the nonfinancial public sector increased its deposits at the central bank by 4.8 percent of GDP, while the Social Security Board (SSB) increased its lending to the private sector by 2.3 percent of GDP. The SSB provided mortgage financing and crop financing for the citrus and banana industries, financed in part through securitization of receivables from its mortgage portfolio. ${ }^{7}$

6. As noted above, the operations of the state-owned DFC constitute a key element in the investment and growth strategy of the government. During 2000, the DFC doubled its loan portfolio from BZ\$96 million to BZ\$199 million (12 percent of GDP) (Table 4). In addition, it provided new construction financing and purchased real estate assets for about BZ\$80 million. ${ }^{8}$ Credit activity concentrated on agriculture, industry, and housing (Box 1). The DFC operations were financed through external commercial borrowing in the form of receivables securitization (Box 2) and external commercial borrowing by the central bank onlent to the DFC. The rapid pace of credit expansion was accompanied by a significant increase in nonperforming loans from 16 percent of total loans at end-1999 to 30 percent at

${ }^{5}$ A part of the decline also reflected expenditure reclassification of about $1.1-2.6$ percent of GDP, as transfers by the central government to autonomous entities within the nonfinancial public sector were recorded as capital expenditure

${ }^{6}$ See the companion paper "Selected Issues and Statistical Appendix" for a discussion of external debt.

${ }^{7}$ See the companion paper "Selected Issues and Statistical Appendix" for a discussion of the SSB investment portfolio.

${ }^{8}$ Financing for ongoing construction and real estate assets are classified as "assets held for resale" in the DFC balance sheet pending completion of construction, sale, and issuance of a mortgage. 
the end of 2000 ( 5.7 percent of GDP). ${ }^{9}$ In addition, the leveraged credit expansion undermined the adequacy of the DFC's capital base and of loan loss provisioning for weak assets.

\section{Box 1. Housing Program}

Upon taking office, the current government set a target of 10,000 new houses to be built during 1998 2003. In the past three years, the construction of about 2,500 new houses has been financed with government support. The housing program comprises the following elements:

DFC lending: A key component of the housing program is the provision of mortgage financing by the DFC. This includes financing to credit unions to provide mortgages to their members and construction loans to developers. The DFC's mortgage portfolio increased by BZ\$49.1 million in the past two years (3 percent of GDP). In addition, the DFC's housing inventory increased to BZ\$85.6 million in 2000, reflecting the purchase of houses from a foreign developer in the area of San Pedro that are being sold to the private sector, and work in progress on 1,500 prefabricated houses. The financial resources of the DFC have come mostly from receivables securitization (see Box 2), onlending from the central bank of external loans, and CDB loans for housing. The DFC also contracted a foreign commercial loan in the first quarter of 2001.

Social security lending: The Social Security Board (SSB) has provided about BZ\$10 million to credit unions to provide mortgage financing to their members during 1999-2000. These resources have financed about 100 new houses and improvements to 82 homes. The SSB also securitized receivables from its mortgage portfolio and the proceeds have been used to finance new mortgages.

Housing construction: The housing ministry has provided about 400 houses to low-income households during 1998-2000. These were built by private developers with financing by the ministry, in part from a concessional loan from Taiwan. Upon completion, the houscs were bought by households with mortgage financing provided by the SSB. The government has also begun the development of a new city "La Democracia". This will be a new industrial site with housing for employers and employees and is financed through a suppliers' loan.

Interest rates: The mortgages provided by the DFC and SSB carry interest rates of 12 percent. This has led to a decline in commercial bank mortgage interest rates to an average of 14.7 percent at endDecember 2000 compared to 15.7 percent at end-December 1998.

\footnotetext{
${ }^{9}$ Nonperforming loans might be somewhat overstated due to software and management practices in use at the DFC.
} 


\section{Box 2. Receivables Securitization Operations}

In 1999 and 2000, the DFC and the SSB sold securities to a foreign bank in an amount of US $\$ 102.2$ million and pledged the income stream from a specific domestic portfolio of mortgages and other collateralized loans for their repayment. These operations are a variation of mortgage-backed securitization as they involve the pledging of income streams from mortgages and other financial assets. However, the financial assets were not sold but rather used as collateral, i.e., the risk of the financial assets remains with the DFC or SSB. To obtain the financing, the DFC and the SSB guaranteed the income streams of the loan portfolios, the government provided a subsidiary guarantee, and the central bank guaranteed the convertibility into U.S. dollars of the income stream of the portfolios, which is in Belizean dollars. In this process, the public sector of Belize has assumed the credit, liquidity, and exchange rate risks inherent in the operation.

These operations were carried out in four tranches with different financial characteristics. Three tranches sold between April 1999 and March 2000 carried bullet maturity repayments and have sinking funds assigned to them to accumulate funds for their repayment, while debt service on the fourth tranche sold in August 2000 is paid in equal payments (like a typical mortgage).

The DFC and the SSB intend to continue securitization operations in the future to fund their lending activity in Belize, but expect to move toward more traditional mortgage securitization.

7. The net domestic assets of the central bank declined by BZ\$90 million in 2000 (78 percent of currency issue at end-1999), reflecting the large build-up of deposits by the central government and notwithstanding the issuance of credit by the central bank to the DFC of BZ $\$ 84.5$ million during the year (Table 5). The currency issue expanded by 11 percent, which combined with a 10 percent increase in private sector deposits at commercial banks contributed to a strong growth in broad money. At the same time, the growth in bank credit to the private sector slowed, partly because of the availability of DFC and SSB credit at lower rates and longer maturities. As a result of this and an increase in unsatisfied demand for foreign exchange, the commercial banks built up excess liquidity and their reserve position at the CBB increased from BZ\$39 million at end-1999 to BZ\$82 million at end-2000 (15 percent of deposits), and are in some cases refusing to open new deposit accounts. Nominal lending rates decreased slightly to about 15.9 percent, due to the expansion of liquidity and the availability of credit through the DFC and the SSB. However, commercial bank spreads remained at around 10 percent.

\section{The external current account deficit rose from 9 percent of GDP in 1999 to} 16 percent of GDP in 2000, reflecting mainly a sharp growth in imports of machinery, transport equipment, and manufactured goods (Table 6). Exports stagnated despite large increases in citrus concentrate and banana shipments, as prices declined. Net capital inflows increased sharply to US\$183 million (22 percent of GDP) as a result of the substantial borrowing by the public sector and higher privatization proceeds. The gross international reserves at the CBB increased to about $2 \frac{1}{2}$ months of imports of goods and services. 
However, about 30 percent of the total gross reserves of US\$114 million at end-2000 were held as collateral against loans and were not freely usable. Reflecting the increased borrowing, public and publicly guaranteed external debt increased substantially from 48 percent of GDP at end-1999 to 67 percent at end-2000 and the debt service is beginning to strain the public finances (Table 7 and Figure 2). The central bank has continued its policy of rationing foreign exchange, making funds available to cover payments abroad for essential items, such as food, fuel and insurance, while delaying sales of foreign exchange for other purposes, including some current transactions. The foreign exchange market in Belize is highly segmented. The CBB purchases the foreign exchange from sugar exports (about 12 percent of current account receipts), while other foreign exchange receipts are sold bilaterally between major exporters and importers or through the commercial banking system. Reports indicate that the parallel market exchange rate had depreciated to BZ\$2.152.20 per US\$1 by May 2001 from around BZ\$2.05-2.10 per US\$1 a year earlier.

Figure 2. Belize: External Public and Publicly Guaranteed Debt (In millions of U.S. dollars)

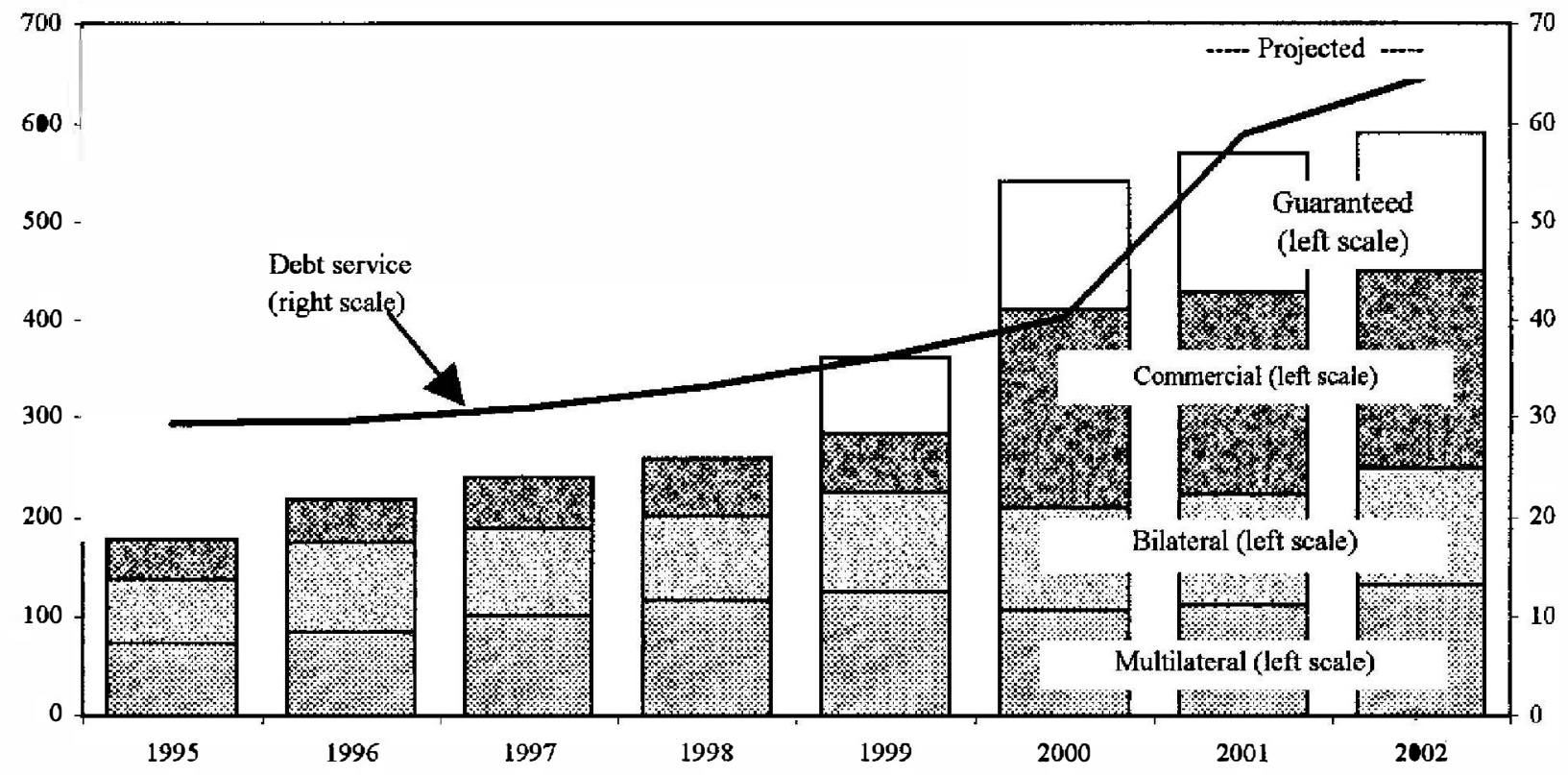

\section{Policy Discussions}

\section{In the discussions, the authorities noted that their economic strategy had} resulted in a substantial pick-up in economic growth. They expected real GDP growth in 2001-03 to average 8.5 percent on the continued strength of growth in shrimp farming and tourism, while consumer prices were seen to rise in line with inflation in trading partner countries. The staff and authorities concurred on the need to contain the fiscal deficits after the expenditure overruns in FY 2000/01, reducing the nonfinancial public sector deficit 
gradually to about 1 percent of GDP over a three-year period. The authorities also indicated that the nonfinancial public sector would refrain from further international bond financing during that period, but did not rule out other forms of commercial borrowing. They explained that lending activity of the DFC would continue, albeit at a reduced expansion rate, financed through a continuation of the program to securitize receivables.

10. The mission underscored the urgency of reducing the fiscal imbalance to prevent the external debt burden and the excess liquidity in the system from undermining private sector confidence and economic growth. The mission urged the authorities to refrain from contracting any further external debt on commercial terms, including through receivables securitization by the DFC. In this context, the mission pointed out that continued credit expansion by the DFC with external resources would exacerbate the external debt burden, increase excess liquidity further, and create pressures in the foreign exchange markets. In addition, new credit operations were likely to further undermine the solvency of the DFC.

\section{The mission discussed with the authorities a medium-term scenario that would} achieve a sustainable position of the nonfinancial public sector. The scenario foresees a reduction in the deficit to 1 percent of GDP over three years and would be consistent with a reduction in the external public debt in relation to GDP. Together with a curtailment of DFC credit expansion, it would permit a strengthening of the external position and allow the central bank to stop rationing foreign exchange. The public sector borrowing requirement over the three-year adjustment period could be covered through the drawdown of deposits at the central bank. The fiscal consolidation could be achieved through a reduction of capital expenditure to historical levels and increases in revenue.

\section{The authorities agreed that a reduction of the fiscal deficit to about 1 percent of} GDP over three years was of the utmost importance and that the adjustment process should commence in FY 2001/02. They recognized that complementing privatization revenue with large commercial borrowing had involved certain risks, but felt that the strategy had been appropriate and noted that few alternatives had been available for achieving the objectives of accelerating growth and reducing poverty. They expected that the recent investment projects in shrimp farming, tourism, and other areas would help sustain high levels of growth and that tax revenue would increase over the medium term. The staff cautioned that the sectors mentioned as engines of growth enjoyed extensive tax incentives and were also capital-intensive, providing little opportunity for employment generation and payroll taxation. The authorities were of the view that DFC operations entailed only limited macroeconomic risks and should be continued to provide financing in areas where the domestic banking system was unwilling to participate, particularly in the areas of long-term and industrial and agricultural sector lending. The staff took the view that it would be important to limit the expansion of DFC operations to safeguard the solvency of the DFC and to avoid distortions in the pricing of risk in the credit markets. The staff also noted that it would be more prudent and realistic to project medium-term fiscal policy and the public sector's debt servicing capacity on the assumption of a more modest rate of growth. 


\section{A. Fiscal Policy}

13. In line with the three-year adjustment scenario, the nonfinancial public sector deficit should decline to 5.7 percent of GDP in the current fiscal year, mainly through a reduction in capital spending of almost 5 percent of GDP. This deficit could be financed through a partial drawdown of the deposit from the recently disbursed external loan, as noted above, privatization receipts from the sale of the Belize City port, and disbursements from multilateral and bilateral sources.

\section{With regard to the central government, the authorities intend to contain the} deficit within the limits envisaged under the normative three-year adjustment scenario prepared by the mission. To achieve this, they would seek to contain current expenditure growth to 2 percent on average over the next three years. To contain expenditure during FY 2001/02, the authorities were implementing an across-the-board cut in current primary expenditure of about 1.5 percent of GDP and improving budget execution and monitoring with the help of a recently implemented cash warrant system developed with assistance from the United Kingdom. Interest payments would increase from 2.4 percent of GDP in FY 2000/01 to 2.9 percent of GDP in FY 2001/02, reflecting the additional external debt contracted in FY 2000/01. Capital spending would fall significantly, reflecting the completion of a number of domestically financed projects and a reduction in hurricanereconstruction expenditure. The reduced investment program would include projects supported by multilateral creditors, including continued highway construction, a low-income housing program, as well as a project to enhance the tourism value of major archeological sites.

\section{The rest of the nonfinancial public sector is expected to record a small overall} surplus in FY 2001/02. The improvement would reflect mainly increased contributions to the social security system following a rise in the contribution rates. ${ }^{10}$ Capital expenditure would decline sharply following the privatization of WASA, the water and sewerage company. From FY 2001/02, only the port and airport authorities will remain as public enterprises. The port facilities have been upgraded in the past three years, and with the rebound in economic activity the Port Authority is now running a small operational surplus. The authorities plan to privatize the Belize City port in the first half of FY 2001/02. The airport authority has expanded the Belize City airport in recent years, accumulating significant debt-service obligations, and despite improvement in its management continues to record operational losses. The authorities are now in discussion with a major European airport service company to improve management practices further and implement changes in preparation for the privatization of the airport in FY 2002/03.

${ }^{10}$ See the companion paper "Selected Issues and Statistical Appendix" for a discussion of the recent social security reform. 
16. The staff expressed concern about the difficulties in raising revenue and containing current and capital outlays as needed to achieve the government's fiscal consolidation plans. The concerns about revenue mobilization reflected the lack of buoyancy of the tax regime in place since 1999 and the tax-sheltered status of the sectors expected to lead the economic growth. The staff therefore suggested that additional fiscal measures may be needed, such as a reduction in import duty and tax exemptions, and the reversal of some of the 1999 tax cuts. Tariffication of quantitative import restrictions could also provide some additional revenue. As regards expenditure, the staff pointed out that the authorities had been unable to contain expenditure within the budgeted levels for a number of years, and noted that orderly expenditure cuts require careful planning and implementation and may not yield immediate savings. In addition, the staff also cautioned that the authorities might face difficulties in mobilizing political support for expenditure reductions in light of the elections that should take place within the next two years. In response, the authorities noted that their FY 2001/02 budget calls for a 3.7 percent of GDP deficit, well within the envisaged adjustment path, and that improved budget control mechanisms were in place. Also, the authorities maintained that tax increases would not be necessary to achieve a sustainable fiscal position, and that improved revenue administration would suffice to achieve the needed revenue collection objectives.

\section{The authorities saw the lending activities of the DFC as a centerpiece of their} strategy to foster private sector investment and provide financing for low-income housing. The staff pointed out that the DFC's external borrowing activity, including through the intermediation of the CBB, had increased Belize's external debt to critical levels and that further DFC lending operations financed through borrowing, including against receivables, could further impair the solvency of the DFC. The activity of the DFC had also reduced intermediation through the banking system. Moreover, the insufficient capital base, the high loan delinquency, and the undisbursed loan commitments of the DFC could lead to cash-flow shortfalls. The government pointed out that they were committed to a continuation of the DFC operations as commercial banks were unwilling to provide sufficient longer-term financing, in particular to industry and agriculture and for housing. They also noted that they were instituting measures to improve operations at the DFC, including through an audit planned by the CDB and Fund technical assistance to review and improve management practices at the DFC, and pointed out that the DFC would be subject to the same prudential norms and regulatory oversight as the banking sector in the course of 2001 .

\section{B. Monetary Policy}

18. Central to monetary policy is the need to reduce the excess liquidity in the system to help secure the sustainability of the exchange rate peg and help contain inflationary pressures. For 2001, the central bank projects an expansion in its net domestic assets of about BZ\$25 million, based on the expected reduction of central government deposits at the central bank, and a similar loss of net international reserves as the central bank absorbs liquidity. 
19. The only instruments of monetary policy, besides foreign exchange market intervention, are direct credit allocation by the central bank, and the reserve and liquid asset requirements. The staff and the authorities agreed that domestic capital markets were too thin for an effective use of more flexible, market-based instruments, such as open market operations.

20. In 2001, the central bank will not provide additional credit to the DFC and will reduce its net international reserves in line with the deposit withdrawals by the central government. The current cash and liquid asset requirements are of little practical importance at this stage, as commercial banks hold large unremunerated excess reserves at the central bank. Over the medium term, the central bank plans to reduce excess liquidity through a continuous reduction in net credit to the public sector and the sale of foreign exchange from multilateral project borrowing. In the future, the CBB plans to lower the cash reserve requirements and expand the range of assets that would qualify under the liquid asset requirement, but that would be done only after fiscal consolidation has taken place. The authorities expect that this will help narrow the spread between deposit and lending interest rates which has increased gradually in recent years to 10 percentage points at end-2000, in part due to the increased liquidity overhang in the economy. The staff supported the central bank's intention to reduce bank liquidity, but noted that the reduction in 2001 would be modest, as loan repayments to the CBB by the DFC would be small and that the scope for additional foreign exchange sales to the private sector was constrained by the need to maintain an adequate level of net international reserves.

\section{External Sector}

\section{As a result of the envisaged improvement in the overall position of the public} sector, the external current account deficit would narrow to about 12 percent of GDP in 2001. Sales of stockpiled citrus concentrates and higher shrimp production are projected to boost exports, while imports would increase only modestly, reflecting the reduced need for construction material for hurricane damage reconstruction and public housing. Tourist receipts are expected to rise with the completion of a new hotel and new docking facilities for cruise ships. Net capital inflows are projected to fall to 11 percent of GDP from 22 percent in 2000 , reflecting a sharp reduction in borrowing by the public sector and only a moderate increase in private capital inflows. On this basis, the external public and publicly guaranteed debt would remain at around 68 percent of GDP, with debt service amounting to 13 percent of exports of goods and services. The projected overall deficit of the balance of payments of US $\$ 11$ million would reduce gross reserves to about 2.3 months of imports of goods and services.

\section{The authorities reaffirmed their commitment to the exchange rate peg at its} current level to provide an anchor for confidence. The staff agreed that the fixed exchange rate peg had served the country well in the past, but remarked that the fiscal and monetary policy stance in 2000 had exacerbated the foreign exchange rationing system. The authorities explained that banks and exporters were hoarding foreign exchange, making it necessary to prioritize the use of foreign exchange resources. Nonetheless, they agreed that the need for 
rationing reflected the expansionary policy stance and pointed to the planned fiscal consolidation and a reduction of excess liquidity as measures that would obviate the need for rationing and reducing or eliminating the parallel market. The staff pointed out that current policies had undermined competitiveness, ${ }^{11}$ and that a fiscal adjustment as envisaged by staff and agreed to by the authorities was essential. The staff noted that the rationing had created inefficiencies in resource allocation, reduced financial intermediation, and created disincentives for private investment. The rationing was also discriminatory and resulted in undue payments delays, giving rise to payment arrears and to exchange restrictions subject to Fund approval.

\section{Structural Policies}

\section{The authorities intend to privatize the remaining public enterprises (the port} and airport authorities) by 2003, to raise funds for investment expenditure and help reduce the costs of operating these entities and improve their competitiveness. The cost of electricity, ports, and telecommunication services in Belize is generally much higher than in other Central American or Caribbean countries. The authorities noted that the telecommunications monopoly granted to Belize Telecommunications Limited (BTL) will expire in 2002 and expected that increased competition will lead to improved services and lower rates.

\section{The authorities implemented the last stage of the CARICOM common external} tariff reduction in April 2000, by reducing maximum rates from 25 percent to 20 percent. Nonetheless, Belize's trade system remains fairly restrictive, with an average import tariff of over 11 percent and quantitative import restrictions on 29 groups of goods, mostly food items. The staff pointed out that the replacement of quantitative import restrictions with tariffs would improve resource allocation and likely also provide additional fiscal revenue. The staff also pointed to the adverse effect of the import duty exemptions (sometimes granted on an ad-hoc basis) on resource allocation and fiscal revenue. In April 2001, the United States and the European Union agreed on a revision of the European banana import regime. The regime change will maintain quotas based on historical deliveries until 2006, when a tariff-only regime will be introduced. The authorities noted that Belize's banana industry will benefit from the transitional regime and are confident that it will be internationally competitive by 2006 . Belize is continuing to negotiate bilateral trade agreements with several countries, including Mexico and the other countries in Central America.

25. The staff agreed with the authorities' view that supervision of both onshore and offshore financial institutions needed to be strengthened. While nonperforming loans of

${ }^{11}$ See the companion paper "Selected Issues and Statistical Appendix" for a discussion of external competitiveness issues. 
commercial banks were only 6.2 percent of total loans as of end-December 2000, the central bank's supervisory department is severely understaffed and faces difficulties in enforcing the existing banking law and regulations. ${ }^{12}$ Moreover, credit unions are subject to weak regulation, while building societies and the DFC remain unregulated. The staff recommended that the central bank strengthen its supervisory department, and conduct annual on-site inspections of each bank. In addition, a strengthening of the supervisory department would be necessary as supervision will be extended to the DFC later in 2001. MAE will provide technical assistance in the area of banking supervision in 2001 and will also review the management practices and operations of the DFC.

\section{The offshore sector consists of two banks and over $\mathbf{1 0 , 0 0 0}$ registered companies.}

The authorities were of the view that this sector has the potential for contributing significantly to economic growth, and legislation has been passed in recent years to broaden the range of onshore and offshore financial institutions operating in Belize. The authorities also noted that Belize had not been named as a noncooperative country in the international fight against money laundering, although it had been mentioned by the Financial Stability Forum as having a low quality of financial sector supervision and had been placed by the OECD on the list of tax havens. The staff noted that it would be important for the central bank to conduct on-site inspections of the offshore banks operating in Belize to prevent transactions between the onshore and offshore financial institutions, and to curtail or abolish the use of bearer shares, which can hide the identity of corporate ownership and allow residents to conduct offshore operations. The mission also recommended that the authorities request an offshore financial center assessment from the Fund.

\section{The authorities' strategy for poverty reduction focuses on employment} generation through economic growth, the provision of low-income housing, and improved access to and quality of social services. Belize's social indicators compare favorably with neighboring countries, although poverty affects indigenous groups in the South more severely. The last poverty assessment, conducted by the CDB in 1996, estimated that 33 percent of the population lived below the poverty line, while about 13 percent were considered extremely poor. ${ }^{13}$ The authorities pointed to the construction of low-income housing as a centerpiece of the government's policies to combat poverty (see Box 1). They have also developed a ten-year plan with support from the World Bank to improve education through teacher training and curriculum reform. A health sector pilot project is being implemented with the support of the Inter-American Development Bank, that will lead to the establishment of a national health insurance plan.

12 The Banks and Financial Institutions Act of 1996 strengthened the regulatory authority of the central bank and established prudential regulations in line with core principles as recommended by the Basel Committee.

${ }^{13}$ The poverty line was estimated at BZ\$1,288 a year, while the extreme poverty line was estimated at BZ\$751 a year. 


\section{E. Statistical Issues}

\section{The quality of Belize's statistical information is in some areas inadequate to} monitor economic developments on a timely basis. Belize reports economic data to the Fund with some delays, and the quality, frequency, and timeliness of some economic statistics needs strengthening (Appendix V). The national income accounts are based on a 1984 survey and are only available on a calendar-year basis, hindering timely analysis. The consumer price index is prepared quarterly and is based on an outdated survey of consumption patterns. Data on the operations of public enterprises and a financial survey that includes credit unions are reported with long delays. The data on public investment spending include some outlays for transfers that should be classified as current expenditure. Balance of payments data are only compiled on an annual calendar-year basis. Tourism statistics suffer from inconsistencies in reporting from different sources. The authorities attributed these difficulties to the high turnover among qualified staff in the public sector and would appreciate technical assistance in improving the quality of their economic statistics. The Fund provided technical assistance in April 2001 to improve balance of payments statistics and facilitate the transition to the fifth edition of the Balance of Payments Mamual (BPM5).

\section{MEDIUM-TERM OUTLOOK}

\section{The staff presented to the authorities a medium-term scenario based on real} GDP growth of 5 percent a year during 2001-05 aimed at achieving sustainable fiscal and external positions (Table 8). Under this scenario, the savings-investment imbalance of the public sector would be reduced to allow for a reduction of the crowding-out of the private sector in line with achieving balance of payments viability. Accordingly, the nonfinancial public sector deficit would need to improve to 1 percent of GDP by FY 2003/04, with annual net external financing of 2 percent of GDP. To achieve this, public capital outlays would need to be compressed to $81 / 2$ percent of GDP by FY 2003/04, returning to historic levels of around 10 percent thereafter as public savings would improve to provide sufficient financing. On this basis, the external current account deficit would decline rapidly to around 6 percent of GDP by 2002 and continue a gradual improvement thereafter. Net international reserves would increase to about three months of imports by 2005 . The external public debt would decline from 67 percent of GDP at present to about 58 percent of GDP by 2005, while debt service payments would remain above 25 percent of central government current revenue during the entire period. This debt-service could be financed through external borrowing. A strong fiscal policy, the curtailment of DFC operations, and the elimination of the liquidity overhang through the sale of foreign exchange from central government external financing and a continued decline in central bank credit to the public sector would enable the central bank to stop rationing foreign exchange.

30. The fiscal adjustment path outlined in this medium-term scenario would require a sharp reduction in public investment over the next two years. In addition, revenue-enhancing measures of about 3 percent of GDP would be necessary to counter the decline in tax collections in recent years. Such measures could include the elimination of exemptions from 
taxes and import duties, which could boost tax revenues by $1 \frac{1 / 2-2}{2}$ percent of GDP. The staff noted that there were few viable alternatives to the fiscal path presented in the medium-term scenario, as further financing through external borrowing would lead to unsustainable debt levels, while domestic financing could further undermine the exchange rate peg. The authorities agreed with the need to reduce permanently the nonfinancial public sector deficit to a sustainable level, and noted that their FY 2001/02 budget aims to contain the deficit at a level well within the framework of the scenario drawn up by staff. However, the authorities were of the view that tax increases would not be necessary to attain a sustainable fiscal position.

\section{STAFf APPRaISaL}

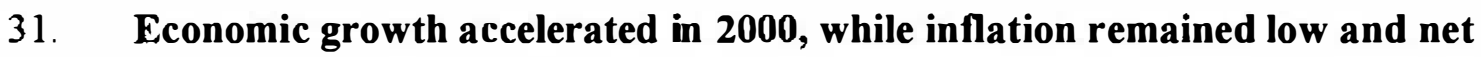
international reserves grew. However, the fiscal and the external current account deficits continued to widen to clearly unsustainable levels. As a result, the external public debt has increased substantially and the debt service payments are beginning to strain the public finances. At the same time, monetization of external loans has increased the excess liquidity in the system, exacerbating foreign exchange restrictions and creating pressures in the foreign exchange markets. To re-establish a sustainable fiscal and external position, including a manageable external debt burden and credible exchange rate peg, the staff will urge the authorities to reduce the fiscal deficit to about 1 percent of GDP over a three-year period.

32. On this basis, the fiscal deficits during the next three years can be financed entirely through funds deposited at the central bank from a recently disbursed external commercial loan. While the staff welcomes the authorities' commitment to refrain from further external bond financing, the staff believes that any further external financing on commercial terms should be avoided.

33. The state-owned DFC has increased its lending activities significantly, financing its operations through external borrowing. This lending program has exacerbated the domestic liquidity overhang and reduced bank intermediation, while the foreign financing of the DFC has added to the public sector debt burden. High-loan delinquency rates are undermining the solvency of the DFC and the staff urges the authorities to restrict DFC credit expansion and refrain from any further external financing. The staff welcomes the authorities' request for Fund technical assistance to review and improve management practices at the DFC, and their decisions to refrain from further central bank lending to the $\mathrm{DFC}$, and to subject the DFC to banking supervision.

34. The staff is concerned about the achievement of the planned fiscal adjustment, as spending pressures in the past have led to significant budget overruns. The budget for FY 2001/02 is consistent with an adjustment path toward a medium-term sustainable fiscal position, and efforts are being made to reduce budget allocations and improve expenditure monitoring. Nevertheless, the staff believes that a significant effort will be necessary to enforce expenditure cuts of a magnitude necessary to achieve a sustainable fiscal position in 
three years, and the authorities would need to mobilize political support for the required fiscal tightening. The staff is of the view that efforts should be concentrated on scaling back those domestically financed projects that have relatively low rates of return, and public support for private housing construction should be limited to a well-focused low-income housing program.

35. Central to monetary policy is the need to reduce excess liquidity in the system to help secure the sustainability of the exchange rate peg. The authorities intend to induce this reduction through a continuous decline in net central bank credit to the public sector and the sale of foreign exchange from multilateral project borrowing. The staff welcomes the authorities' decision to refrain from issuing new central bank credit to the DFC and believes that a continuation of such a policy would be essential to help reduce excess liquidity.

\section{The central bank's capacity to supervise commercial banks needs to be} strengthened, particularly as the authorities intend to extend supervision to the DFC. The staff weicomes the authorities' interest in receiving further technical assistance from MAE to strengthen bank supervision. The staff will recommend that legislation be enacted to give the central bank supervisory authority over credit unions, other nonbank financial intermediaries, and the offshore financial sector.

37. The reduction in the maximum external tariff rate from 25 percent to 20 percent has moved Belize's trade system in the right direction. At the same time, tariffs remain high and 29 groups of goods are subjected to quantitative import restrictions. The staff recommends that the remaining quantitative import restrictions be converted into tariffs. The elimination of ad-hoc duty exemptions would also improve transparency and resource allocation.

38. The staff notes that the ad hoc rationing of foreign currency sales by the central bank constitutes an exchange restriction subject to Fund approval under Article VIII. As the authorities do not have a clear timetable for phasing out this restriction, Fund approval for its retention is not recommended.

39. Belize's statistical information is weak and needs to be improved to facilitate a more effective monitoring of economic developments. The staff notes the authorities' strong interest in receiving technical assistance to improve the quality of economic statistics, particularly in the areas of balance of payments and national accounts.

40. The next Article IV consultation with Belize is expected to be held on the standard 12-month cycle. 
Table 1. Belize: Selected Economic and Banking Sector Indicators, 1997-2001

\begin{tabular}{|c|c|c|c|c|c|}
\hline & 1997 & 1998 & 1999 & 2000 & $\begin{array}{l}\text { Proj. } \\
2001\end{array}$ \\
\hline \multicolumn{6}{|c|}{ (Annual percentage changes, unless otherwise specified) } \\
\hline $\begin{array}{l}\text { National income and prices } \\
\text { GDP at factor cost, constant prices } \\
\text { Consumer prices (end of period) }\end{array}$ & $\begin{array}{r}3.2 \\
-0.6\end{array}$ & $\begin{array}{r}1.5 \\
-0.8\end{array}$ & $\begin{array}{r}6.5 \\
-1.1\end{array}$ & $\begin{array}{r}10.4 \\
1.0\end{array}$ & $\begin{array}{l}5.0 \\
1.0\end{array}$ \\
\hline $\begin{array}{l}\text { Externsl sector (U.S. dollars) } \\
\text { Total exports, f.o.b. } \\
\text { Imports, c.if. } \\
\text { Terms of trade (deterioration -) } \\
\text { Nominal effective exchange rate 1/ } \\
\text { Real effective exchange rate 1/ } \\
\text { Export volume } 2 /\end{array}$ & $\begin{array}{r}16.6 \\
21.3 \\
-5.9 \\
6.4 \\
3.1 \\
10.6\end{array}$ & $\begin{array}{r}-2.8 \\
4.6 \\
8.5 \\
-1.3 \\
-4.2 \\
-6.4\end{array}$ & $\begin{array}{r}9.6 \\
15.8 \\
-12.5 \\
3.2 \\
-0.3 \\
0.1\end{array}$ & $\begin{array}{r}-0.4 \\
19.5 \\
-10.7 \\
5.4 \\
3.8 \\
21.7\end{array}$ & $\begin{array}{r}14.1 \\
2.4 \\
1.9 \\
\ldots \\
1 \ldots \\
8.3\end{array}$ \\
\hline $\begin{array}{l}\text { Nonfinancial public sector } 3 \text { / } \\
\text { Revenue } \\
\text { Current expenditure } \\
\text { Capital expenditure }\end{array}$ & $\begin{array}{r}0.7 \\
-3.1 \\
49.8\end{array}$ & $\begin{array}{r}5.5 \\
7.9 \\
15.5\end{array}$ & $\begin{array}{r}-1.1 \\
9.1 \\
10.5\end{array}$ & $\begin{array}{r}6.6 \\
0.4 \\
30.2\end{array}$ & $\begin{array}{r}6.1 \\
10.2 \\
-26.0\end{array}$ \\
\hline $\begin{array}{l}\text { Money and credit } \\
\text { Net domestic assets } 4 \text { / } \\
\text { Credit to the public sector (net) } \\
\text { Credit to the private soctos } \\
\text { Money and quasi-money (M2) 4/ } \\
\text { Velocity (M2) } \\
\text { Average deposit rate (end of period) } \\
\text { Average lending rate (end of period) }\end{array}$ & $\begin{array}{r}12.6 \\
2.0 \\
10.5 \\
7.3 \\
2.1 \\
6.7 \\
16.5\end{array}$ & $\begin{array}{r}15.1 \\
5.1 \\
9.6 \\
6.4 \\
2.1 \\
6.1 \\
16.4\end{array}$ & $\begin{array}{r}6.1 \\
-1.8 \\
7.9 \\
10.8 \\
2.0 \\
5.7 \\
16.2\end{array}$ & $\begin{array}{r}0.3 \\
-5.4 \\
5.7 \\
12.9 \\
2.0 \\
5.0 \\
15.8\end{array}$ & $\begin{array}{l}7.7 \\
4.3 \\
3.3 \\
3.2 \\
2.0 \\
\cdots\end{array}$ \\
\hline \multicolumn{6}{|c|}{ (In percent of GDP) } \\
\hline $\begin{array}{l}\text { Nonfinancial public sector } \mathbf{3 /} \\
\text { Current savings } \\
\text { Capital expenditure } \\
\text { Public sector overall balance } \\
\text { Privatization } \\
\text { Public sector borrowing requirement } \\
\text { Foreign Mnancing } \\
\text { Domestic financing } \\
\text { Exceptional financing 5/ }\end{array}$ & $\begin{array}{r}5.5 \\
11.9 \\
-4.2 \\
0.0 \\
4.2 \\
3.8 \\
0.4 \\
0.0\end{array}$ & $\begin{array}{r}4.6 \\
13.1 \\
-6.0 \\
0.0 \\
6.0 \\
3.3 \\
2.7 \\
0.0\end{array}$ & $\begin{array}{r}2.8 \\
13.0 \\
-8.2 \\
3.9 \\
4.3 \\
4.2 \\
-1.7 \\
1.8\end{array}$ & $\begin{array}{r}3.5 \\
15.5 \\
-9.7 \\
3.2 \\
6.4 \\
12.3 \\
-6.1 \\
0.2\end{array}$ & $\begin{array}{r}3.1 \\
10.8 \\
-5.7 \\
2.6 \\
3.1 \\
2.9 \\
0.2 \\
0.0\end{array}$ \\
\hline $\begin{array}{l}\text { Gross domestic investment } \\
\text { Gross national savings }\end{array}$ & $\begin{array}{l}24.8 \\
21.3\end{array}$ & $\begin{array}{l}25.8 \\
19.6\end{array}$ & $\begin{array}{l}27.5 \\
18.4\end{array}$ & $\begin{array}{l}31.6 \\
15.5\end{array}$ & $\begin{array}{l}28.9 \\
16.6\end{array}$ \\
\hline $\begin{array}{l}\text { External current account } 6 / \\
\text { Public extemal debt (end of period) } 7 /\end{array}$ & $\begin{array}{r}-3.5 \\
37.2\end{array}$ & $\begin{array}{r}-6.2 \\
38.6\end{array}$ & $\begin{array}{r}-9.0 \\
48.3\end{array}$ & $\begin{array}{r}-16.1 \\
67.4\end{array}$ & $\begin{array}{r}-12.3 \\
68.2\end{array}$ \\
\hline \multicolumn{6}{|c|}{ (In percent of exports of goods and services) } \\
\hline $\begin{array}{l}\text { Debt } 7 / \\
\text { Debt service } 8 \text { / }\end{array}$ & $\begin{array}{r}70.7 \\
9.1\end{array}$ & $\begin{array}{r}76.4 \\
9.8\end{array}$ & $\begin{array}{r}95.9 \\
9.6\end{array}$ & $\begin{array}{r}143.7 \\
10.5\end{array}$ & $\begin{array}{r}126.8 \\
13.1\end{array}$ \\
\hline \multicolumn{6}{|c|}{ (In pencent of central govemment current revenue) } \\
\hline $\begin{array}{l}\text { Debt service 8/ } \\
\text { Central government debt service } 3 / 8 / \\
\text { (In milli }\end{array}$ & $\begin{array}{l}21.6 \\
16.3 \\
\text { dollars }\end{array}$ & $\begin{array}{r}22.0 \\
15.2 \\
\text { otherw }\end{array}$ & $\begin{array}{r}23.4 \\
16.0 \\
\text { fied) }\end{array}$ & $\begin{array}{l}24.6 \\
19.4\end{array}$ & $\begin{array}{l}33.4 \\
23.1\end{array}$ \\
\hline $\begin{array}{l}\text { Overall balance of payments } \\
\text { Gross official reserves (end of period) 9/ }\end{array}$ & $\begin{array}{r}-0.4 \\
1.5\end{array}$ & $\begin{array}{r}-13.3 \\
1.0\end{array}$ & $\begin{array}{r}27.7 \\
1.5\end{array}$ & $\begin{array}{r}50.6 \\
2.5\end{array}$ & $\begin{array}{r}-11.2 \\
2.3\end{array}$ \\
\hline
\end{tabular}

Sources: Belize authorities; and Fund staff estimates and projections.

1/ End of period; depreciation ( - ).

2/Major commodity exports.

3/ Fiscal year starts on April 1.

$4 /$ In relation to liabilities to the private sector at the beginning of the period.

$5 /$ Sale of mortgages.

$6 /$ Including official grants.

7/ Public and publicly guaranteed external debt.

$8 /$ Public extemal debt.

9/ In months of imports of goods and services over the next 12 months.

CInternational Monetary Fund. Not for Redistribution 
Table 2. Belize: Consolidated Operations of the Nonfinancial Public Sector, $1997 / 98-2001 / 02$

(In percent of GDP)

$1997 / 98 \quad 1998 / 991999 / 2000 \quad \begin{gathered}2000 / 01 \\ \text { Budget }\end{gathered}$ Est. 2001/02

\begin{tabular}{|c|c|c|c|c|c|c|}
\hline Revenue & 28.1 & 28.0 & 25.4 & 25.9 & 24.7 & 24.7 \\
\hline Current revenue & 25.9 & 25.5 & 23.4 & 23.4 & 22.4 & 22.7 \\
\hline Central government & 22.0 & 22.2 & 20.4 & 20.8 & 19.9 & 19.9 \\
\hline Social Security Board & 2.6 & 2.1 & 2.2 & 2.3 & 2.2 & 2.7 \\
\hline NFPE's current surplus & 1.3 & 1.3 & 0.9 & 0.4 & 0.4 & 0.1 \\
\hline Capital revenue and grants & 2.2 & 2.5 & 2.0 & 2.5 & 2.3 & $\mathbf{2 . 0}$ \\
\hline Expenditure & 32.3 & 34.0 & 33.6 & 30.4 & 34.4 & 30.4 \\
\hline Current expenditure & 20.4 & 20.9 & 20.6 & 19.8 & 18.9 & 19.6 \\
\hline Central government & 19.3 & 19.8 & 19.1 & 18.5 & 17.7 & 18.3 \\
\hline Social Security Boand & 1.1 & 1.2 & 1.5 & 1.3 & 1.2 & 1.3 \\
\hline Capital expenditure & 11.9 & 13.1 & 13.0 & 10.7 & 15.5 & 10.8 \\
\hline Central government & 7.3 & 8.7 & 11.8 & 8.5 & 13.8 & 9.9 \\
\hline Social Security Board & 0.5 & 0.7 & 0.2 & 0.5 & 0.1 & 0.5 \\
\hline Public enterprises & 4.1 & 3.7 & 1.0 & 1.7 & 1.7 & 0.4 \\
\hline Overall balance & -4.2 & -6.0 & -8.2 & -4.5 & -9.7 & -5.7 \\
\hline Privatization & 0.0 & 0.0 & 3.9 & 2.2 & 3.2 & 2.6 \\
\hline Public sector borrowing requirement & 4.2 & 6.0 & 4.3 & 4.5 & 6.4 & 3.1 \\
\hline External (net) & 3.8 & 3.3 & 4.2 & 3.1 & 12.3 & 2.9 \\
\hline Domestic & 0.4 & 2.7 & -1.7 & 0.8 & -6.1 & 0.2 \\
\hline Financial system & 0.8 & 2.7 & -0.9 & -1.4 & -3.6 & 1.3 \\
\hline Central bank & 0.3 & 1.6 & -3.2 & -2.6 & -4.8 & 0.9 \\
\hline Commercial banks & 0.5 & 0.7 & 2.3 & 1.2 & 1.2 & 0.4 \\
\hline Development Finance Corporation & 0.0 & 0.4 & 0.0 & 0.0 & 0.0 & 0.0 \\
\hline Nonfinancial system & -0.4 & 0.0 & -1.2 & -0.1 & -0.1 & -0.1 \\
\hline Other $1 /$ & 0.0 & 0.1 & 0.4 & 2.3 & -2.3 & -1.0 \\
\hline Exceptional financing $2 /$ & 0.0 & 0.0 & 1.8 & 0.6 & 0.2 & 0.0 \\
\hline \multicolumn{7}{|l|}{ Memorandum item: } \\
\hline Current savings & 5.5 & 4.6 & 2.8 & 3.7 & 3.5 & 3.1 \\
\hline
\end{tabular}

Sources: Ministry of Finance; Statutory Boards; and Fund staff estimates and projections.

1/ Starting in FY 1999/2000 it reflects the overall balance of the social security invested in the private sector. 2/ Sale of mortgages. 
Table 3. Belize: Operations of the Central Government, 1997/98 - 2001/02

$1997 / 981998 / 991999 / 2000 \quad$ Budget 1/ $\frac{2000 / 01}{\text { Est. }} \quad \begin{array}{r}\text { Proj. } \\ 2001 / 02\end{array}$ (In percent of GDP)

\begin{tabular}{|c|c|c|c|c|c|c|}
\hline Revenue and grants & 24.2 & 24.7 & 22.4 & 23.8 & 22.2 & 21.9 \\
\hline Revenue & 22.9 & 23.5 & 20.9 & 21.8 & 20.8 & 20.5 \\
\hline Current revenue & 22.0 & 22.2 & 20.4 & 20.8 & 19.9 & 19.9 \\
\hline $\operatorname{Tax}$ & 19.7 & 19.8 & 17.4 & 18.4 & 17.9 & 17.9 \\
\hline Nontax & 2.4 & 2.4 & 3.0 & 2.4 & 2.1 & 2.1 \\
\hline Capital revenue & 0.9 & 1.3 & 0.5 & 1.0 & 0.9 & 0.6 \\
\hline Grants & 1.3 & 1.2 & 1.5 & 2.0 & 1.4 & 1.4 \\
\hline Expenditure & 26.6 & 28.5 & 30.9 & 27.0 & 31.4 & 28.2 \\
\hline Current expenditure & 19.3 & 19.8 & 19.1 & 18.5 & 17.7 & 18.3 \\
\hline Wages and salaries & 9.9 & 10.2 & 9.8 & 9.2 & 9.1 & 9.2 \\
\hline Interest payments & 1.9 & 2.0 & 2.0 & 2.4 & 2.4 & 2.9 \\
\hline Goods and services & 4.0 & 4.1 & 4.1 & 3.3 & 3.6 & 3.7 \\
\hline Other & 3.5 & 3.4 & 3.3 & 3.7 & 2.5 & 2.5 \\
\hline Capital expenditure $1 /$ & 7.3 & 8.7 & 11.8 & 8.5 & 13.8 & 9.9 \\
\hline Hurricane reconstruction & 0.0 & 0.0 & 0.0 & 0.0 & 3.0 & 1.7 \\
\hline Non-hurricane reconstruction & 7.3 & 8.7 & 11.8 & 8.5 & 10.8 & 8.2 \\
\hline Overall balance (after grants) & -2.4 & -3.8 & -8.5 & -3.2 & -9.2 & -6.3 \\
\hline Privatization & 0.0 & 0.0 & 3.9 & 2.2 & 3.2 & 2.6 \\
\hline Central government borrowing requirement & 2.4 & 3.8 & 4.7 & 1.0 & 6.0 & 3.7 \\
\hline External (net) & 0.4 & 1.9 & 4.1 & $\ldots$ & 12.0 & 2.9 \\
\hline Domestic & 2.0 & 1.9 & -1.2 & $\ldots$ & -6.2 & 0.8 \\
\hline Financial system & 2.4 & 1.6 & -0.2 & $\ldots$ & -6.1 & 0.9 \\
\hline Nonfinancial system $2 /$ & 0.0 & 0.3 & -1.1 & $\ldots$ & -0.1 & -0.1 \\
\hline Other $3 /$ & -0.3 & 0.0 & 0.0 & $\ldots$ & 0.0 & 0.0 \\
\hline Exceptional financing 4/ & 0.0 & 0.0 & 1.8 & $\ldots$ & 0.2 & 0.0 \\
\hline
\end{tabular}

\section{Revenue and grants}

Revenue

Total expenditure

Current expenditure

Capital expenditure

(Annual percentage change)

$2.5 \quad 7.1$

$-1.7$

2.3

$-3.0$

19.1

\section{8}

12.5

7.6

25.3
0.8

$-1.4$

20.5

7.2

50.5

$\begin{array}{rrr}11.5 & 8.4 & 4.8 \\ 9.8 & 9.0 & 4.8 \\ -8.3 & 11.1 & -4.8 \\ 1.9 & 1.2 & 9.8 \\ -24.7 & 27.1 & -23.4\end{array}$

(In percent of GDP)

Memorandum items:

Current savings

Primary balance

Overall balance excluding

hurricane reconstruction

$\begin{array}{rrrrrr}2.7 & 2.4 & 1.3 & 2.3 & 2.2 & 1.7 \\ -0.5 & -1.8 & -6.5 & -0.8 & -6.8 & -3.4 \\ -2.4 & -3.8 & -8.5 & -3.2 & -6.2 & -4.6\end{array}$

Sources: Ministry of Finance; and Fund staff estimates and projections.

1/ Includes 1.1-2.6 percent of GDP that should be classified as current expenditure in FY 1999/2000 and FY 2000/01.

2/ In FY 1999/2000 it includes repayment of loans to the Social Security Board of about BZ\$14.4 million. Since

FY 1999/2000 it includes an annual payment of BZ\$2 million corresponding to the wage bond issued in FY 1996/97.

3/ Statistical discrepancy.

4/ Sale of mortgages.

CInternational Monetary Fund. Not for Redistribution 
Table 4: Development Finance Corporation

(In millions of Belize dollars)

$\begin{array}{lllll}1996 & 1997 & 1998 & 1999 & 2000\end{array}$

Balance sheet

$\begin{array}{lrrrrr}\text { Assets } & \mathbf{6 1 . 3} & \mathbf{7 0 . 5} & \mathbf{8 0 . 3} & \mathbf{1 4 4 . 0} & \mathbf{3 6 4 . 5} \\ \text { Loan principal } & \mathbf{5 3 . 8} & 60.0 & 66.0 & \mathbf{9 6 . 2} & \mathbf{1 9 9 . 3} \\ \quad \text { Nonperforming loans 1/ } & 6.4 & 7.3 & 10.2 & 15.4 & 60.7 \\ \text { Unassigned performing loans } & 47.4 & 52.7 & 55.8 & 45.1 & 46.9 \\ \text { Assigned performing loans 2/ } & 0.0 & 0.0 & 0.0 & 35.7 & 91.7 \\ \text { Assets held for resale 3/ } & 0.0 & 0.0 & 0.0 & 3.5 & 83.2 \\ \text { Investments } & 1.6 & 1.6 & 1.6 & 1.6 & 2.0 \\ \text { Sinking fund for debt repayment } & 0.0 & 0.0 & 0.0 & 23.7 & 64.0 \\ \text { Cash and deposits } & 0.9 & 3.2 & 1.6 & 11.4 & 10.0 \\ \text { Other assets } & 5.0 & 5.6 & 11.1 & 7.6 & 6.0 \\ & & & & & \\ \text { Liabilities } & 61.3 & 70.5 & 80.3 & 144.0 & 364.5 \\ \text { Current liabilities } & 6.0 & 5.5 & 9.5 & 5.8 & 6.0 \\ \text { Deferred income } & 0.5 & 0.4 & 0.3 & 32.3 & 77.7 \\ \text { Long-term loans } & 39.4 & 47.3 & 50.9 & 60.9 & 196.8 \\ \text { Sinking fund for debt repayment } & 0.0 & 0.0 & 0.0 & 23.7 & 64.0 \\ \text { Other liabilities } & 0.0 & 0.0 & 0.6 & 0.1 & 1.0 \\ \text { Capital, reserves, undistributed profits } & 15.6 & 17.3 & 18.9 & 21.2 & 19.0\end{array}$

\section{Profit and loss statement}

Net interest income

Interest income

Fee and other income

Operating expenses

Financial operations expenses

Overhead

Operating profit cash basis

Accounting income 4/

\section{Memorandum items:}

$\begin{array}{rrrrr}11.9 & 12.2 & 15.5 & 16.0 & 30.5 \\ 10.8 & 10.0 & 10.4 & 7.1 & 4.0\end{array}$

Sources: Audited financial statements (1996-99); and DFC Fund staff estimates (2000).

1/ Nonperforming loans might be overstated as the DFC assigns the last payment by a debtor to the last payment due and not to the oldest overdue payment.

2/ Part of loan portfolio against which DFC borrowed under receivables securitization.

3/ Includes construction-related lending.

4/ Comprises mainly accrued income from receivables securitization.

5/ Nonperfoming loans in percent of total loans. 
Table 5. Belize: Operations of the Banking System, 1997-2001

\section{International reserves (net) \\ Net domestic assets \\ Credit to the public sector (net) \\ Central govemment \\ Rest of the public soctor \\ Net position of commercial banks \\ Development Finance Corporation \\ Medium-term external liabilities \\ Capital and other assets (net)}

Currency iseue

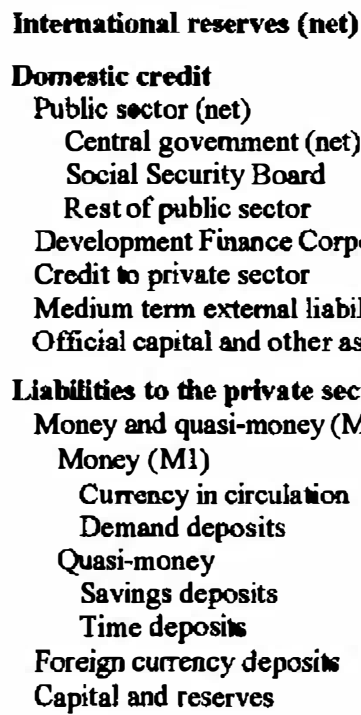

$$
1997
$$

(In millions of Belize dollars)

\section{Central Bank}

$\begin{array}{rrrrr}97.7 & 71.1 & 126.4 & 227.7 & 205.3 \\ -18.5 & 15.6 & -22.6 & -112.4 & -88.8 \\ 44.7 & 85.3 & 40.9 & -15.0 & 14.1 \\ 46.5 & 89.1 & 58.4 & -13.0 & 15.4 \\ -1.8 & -3.8 & -17.5 & -2.0 & -1.3 \\ -44.8 & -47.7 & -38.8 & -81.8 & -84.0 \\ 5.4 & 5.7 & -3.7 & 80.8 & 83.0 \\ -3.1 & -1.9 & -0.6 & -84.0 & -84.0 \\ -20.6 & -25.8 & -20.4 & 12.4 & -17.9 \\ & & & & \\ 79.2 & 86.7 & 103.8 & 115.2 & 116.5\end{array}$

II. Consolidated Banking System

$\begin{array}{rrrrr}87.9 & \mathbf{5 0 . 3} & 119.5 & 235.8 & 197.0 \\ 603.0 & 690.5 & \mathbf{7 2 4 . 5} & \mathbf{7 3 6 . 7} & \mathbf{8 1 1 . 0} \\ 63.3 & 99.4 & 85.8 & 40.4 & 82.5 \\ 103.5 & 135.2 & 132.0 & 57.2 & 82.8 \\ -22.0 & -31.7 & -17.1 & -8.3 & -8.3 \\ -18.2 & -4.1 & -29.1 & -8.5 & 8.1 \\ 5.4 & 5.7 & -3.7 & 80.8 & 83.0 \\ 552.1 & 620.2 & 678.9 & 726.9 & 759.4 \\ -3.1 & -1.9 & -0.6 & -84.0 & -84.0 \\ -14.7 & -32.9 & -35.9 & -27.5 & 53.1 \\ 690.9 & 740.8 & 844.0 & 972.5 & 1,008.0 \\ 607.1 & 651.4 & 731.2 & 840.0 & 870.7 \\ 160.6 & 181.8 & 223.9 & 280.2 & 285.4 \\ 66.4 & 70.4 & 84.2 & 96.0 & 97.0 \\ 94.2 & 111.4 & 139.7 & 184.2 & 188.4 \\ 446.5 & 469.6 & 507.3 & 559.8 & 585.3 \\ 123.0 & 128.2 & 141.2 & 173.5 & 182.4 \\ 323.5 & 341.4 & 366.1 & 386.3 & 402.9 \\ 16.4 & 15.4 & 22.7 & 18.7 & 19.4 \\ 67.4 & 74.0 & 90.1 & 113.8 & 118.0\end{array}$

(Annual changes, as percent of liabilities to private sector at beginning of period)

Net international reserves
Net domestic assets
Credit to the public sector
Credit to the private sector
Money and quasi-money (M2)

\begin{abstract}
Credit to private sector
Liabilities to private sector

Money and quasi-money

Money

Quasi-money
\end{abstract}

Domestic credit

\section{Credit to the public sector \\ Of which \\ Central government}

Credit to the private secwor

Money and quasi-money (M2)

Monetary base

Velocity (M1)

Velocity (M2)

$\begin{array}{rrrrr}-2.7 & -5.4 & 9.3 & 13.8 & -4.0 \\ 12.6 & 15.1 & 6.1 & 0.3 & 7.7 \\ 2.0 & 5.1 & -1.8 & -5.4 & 4.3 \\ 10.5 & 9.6 & 7.9 & 5.7 & 3.3 \\ 7.3 & 6.4 & 10.8 & 12.9 & 3.2\end{array}$

(Annual percentage change)

$\begin{array}{rrrrr}13.7 & 12.3 & 9.5 & 7.1 & 4.5 \\ 9.4 & 7.2 & 13.9 & 15.2 & 3.7 \\ 8.3 & 7.3 & 12.3 & 14.9 & 3.7 \\ 1.4 & 13.2 & 23.2 & 25.1 & 1.9 \\ 11.0 & 5.2 & 8.0 & 10.3 & 4.6\end{array}$

(In percent of GDP, uniess specified otherwise)

$\begin{array}{rrrrr}46.5 & 51.6 & 48.8 & 44.9 & 46.5 \\ 4.9 & 7.4 & 5.8 & 2.5 & 4.7 \\ & & & & \\ 8.0 & 10.1 & 8.9 & 3.5 & 4.7 \\ 42.6 & 46.4 & 45.7 & 44.3 & 43.6 \\ 46.8 & 48.7 & 49.2 & 51.2 & 50.0 \\ 9.6 & 10.1 & 9.6 & 12.0 & 11.6 \\ 8.1 & 7.4 & 6.6 & 5.9 & 6.1 \\ 2.1 & 2.1 & 2.0 & 2.0 & 2.0\end{array}$

Sources: Central Bank of Belize; Fund staff estimates and projections. 
Sorry — content unavailable; section/page intentionally left blank CInternational Monetary Fund. Not for Redistribution 


\section{Table 7. Belize: Indicators of External Vulnerability}

(In percent of GDP, unless othenvise indicated)

\section{Debt indicators}

Total external public debt in pencent of GDP

Public debt

$\begin{array}{rrrrr}34.9 & 37.2 & 38.6 & 48.3 & 67.4 \\ 34.9 & 37.2 & 38.6 & 38.0 & 51.3 \\ 0.0 & 0.0 & 0.0 & 10.3 & 16.0 \\ 71.2 & 70.7 & 76.4 & 95.9 & 143.7 \\ 71.2 & 70.7 & 76.4 & 75.5 & 109.5 \\ 0 & 0 & 0 & 20.4 & 34.2 \\ 4.7 & 4.7 & 5.0 & 4.5 & 4.9 \\ 3.4 & 3.1 & 3.0 & 2.6 & 2.7 \\ 1.3 & 1.6 & 2.0 & 1.9 & 2.2 \\ 9.6 & 9.1 & 9.8 & 9.6 & 10.5 \\ 7.0 & 6.0 & 5.9 & 5.8 & 5.7 \\ 2.6 & 3.0 & 3.9 & 3.9 & 4.8 \\ 21.4 & 21.6 & 22.0 & 23.4 & 24.6 \\ 15.6 & 14.4 & 13.3 & 14.0 & 13.4 \\ 5.8 & 7.2 & 8.8 & 9.4 & 11.3\end{array}$

Publicly guaranteed debt

Total external public debt in percent of exports $1 /$

Public debt

Publicly guaranteed debt

Public debt service in percent of GDP 2/

Amortization

Interest

Public debt service in percent of exports $2 /$

Amortization

Interest

Public debt service in percent of current government revenues $2 /$

Amortization

Interest

\section{Other external indicators}

Exports (percent change, 12-month basis in U.S. dollars) Imports (percent change, 12-month basis in U.S. dollars)

Terms of rade (percent change, 12-month basis)

Real effective exchange rate appreciation $(+)$ (end of period)

Exchange rate (per U.S. dollar, period average)

Current account balance

Capital and financial account balance

Public sector

Private sactor

Gross official reserves (US\$ million)

In months of imports

In percent of amortizations due in the following year In percent of base money

In percent of base money and public sector securities

\begin{tabular}{rrrrr}
4.3 & 16.7 & -2.8 & 9.6 & -0.4 \\
-2.7 & 21.4 & 4.6 & 15.8 & 19.5 \\
2.2 & -5.9 & 8.5 & -12.5 & -10.7 \\
4.1 & 3.1 & -4.2 & -0.3 & 3.8 \\
2.0 & 2.0 & 2.0 & 2.0 & 2.0 \\
-1.1 & -3.5 & -6.2 & -9.0 & -16.1 \\
4.4 & 3.4 & 4.2 & 12.8 & 22.2 \\
5.2 & 4.6 & 2.4 & 9.1 & 25.7 \\
-0.8 & -1.1 & 1.8 & 3.7 & -3.5 \\
51.0 & 52.4 & 37.1 & 64.2 & 114.7 \\
1.5 & 1.5 & 1.0 & 1.5 & 2.5 \\
247.4 & 263.3 & 171.3 & 294.3 & 400.2 \\
86.1 & 83.8 & 54.8 & 89.7 & 116.2 \\
64.5 & 56.0 & 39.0 & 58.0 & 80.9 \\
& & & & \\
& & & & \\
51.0 & 52.4 & 37.1 & 63.7 & 81.7 \\
1.5 & 1.5 & 1.0 & 1.5 & 1.8 \\
247.4 & 263.3 & 171.3 & 292.0 & 285.0 \\
86.1 & 83.8 & 54.8 & 89.0 & 82.8 \\
64.5 & 56.0 & 39.0 & 57.6 & 57.6 \\
\hline
\end{tabular}

\section{Memorandum items:}

Freely available gross official reserves (US\$ million) 3/ In months of imports

In percent of amortizations due in the following year In percent of base money

In percent of base money and public sector securities

Sources: Central Bank of Belize; Ministry of Finance; and Fund staff estimates.

1/ Exports of goods and nonf actor services.

2/ Does not include debt service on publicly guaranteed debt.

3/ Gross official reserves excluding CBB deposits held as collateral in creditor banks. 
Table 8. Belize: Medium-Term Projections

$2000 \quad 2001 \quad 2002$

Projections

$2003 \quad 2004$

2005

(Annual percentage change, unless otherwise indicated)

National income and prices

GDP at constant prices

10.4

Consumer prices (period average)

$\begin{array}{ll}5.0 & 5.0 \\ 1.0 & 1.0\end{array}$

1.0

5.0

5.1

5.1

Money and credit

Net domestic assets //

0.3

7.4

6.7

1.0

1.0

1.0

Credit to the public sector (net) $1 /$

$-5.4$

4.3

$-0.6$

6.7

6.9

6.9

Credit to the private sector $1 /$

5.7

3.1

7.3

$-3.0$

$-3.4$

$-3.5$

Broad money

15.2

3.7

6.2

9.7

10.3

10.3

Velocity (GDP relative to broad money)

1.7

1.7

6.8

7.0

7.0

External sector

Exports

$-0.4$

14.1

1.7

1.7

1.7

1.7

Imports

19.5

2.4

9.8

6.2

9.6

8.8

4.0

6.8

8.2

(In percent of GDP, unless otherwise indicated)

\begin{abstract}
Gross domestic investment
Gross national savings

Private sector savings

Public sector savings

External savings

Private sector

Public sector
\end{abstract}

Nonfinancial public sector balance $2 /$

Total revenue (including grants) $2 /$

Total expenditure $2 /$

Current expenditure $2 /$

Capital expenditure $2 /$

External current account balance

External public and publicly guaranteed debt

Public debt

Publicly-guarantoed debt

External public debt service 3/

In percent exports of goods and services $3 / 4 /$

In percent of central government revenue 3 /

$\begin{array}{lll}31.6 & 28.9 & 25.5\end{array}$

$15.5 \quad 16.6$

12.1

13.4

3.4

$-16.1$

$-4.6$

$-11.5$

$-9.7$

24.8

34.4

18.9

15.5

$$
3.2
$$

$-12.3$

$-3.9$

$-8.4$

19.1

15.2

3.9

$-6.4$

$-1.3$

$-5.1$

$-2.3$

$-5.7$

24.7

30.4

19.6

10.8

$-16.1$

$-12.3$

67.4

68.2

51.8

51.3

16.0

16.4

$\begin{array}{ll}10.5 & 13.1 \\ 24.6 & 33.4\end{array}$

13.1
33.4

13.0

30.6

$-6.4$

66.5

51.2

15.3
26.1

21.7

16.4

5.3

$-4.3$

$-1.2$

$-3.1$

$-1.0$

26.7

27.7

19.3

8.4

$-4.3$

63.6

49.4

14.2

12.6

27.9

11.7

25.6

26.4

27.2

22.9

24.1

16.7

16.7

6.2

7.4

$-3.5$

$-3.1$

$-1.0$

$-1.0$

$-2.5$

$-2.1$

$-1.0$

$-1.0$

27.2

27.7

28.2

28.7

19.3

18.9

8.9

$-3.5$

$-3.1$

60.9

57.7

47.9

45.9

11.8

13.0

14.3

31.2

(In millions of U.S. dollars, unless otherwise indicated)

Overall balance of payments

Gross international reserves

Gross official reserves in months of imports 5/

$\begin{array}{rrr}50.6 & -11.2 & 15.0 \\ 114.7 & 103.5 & 118.4 \\ 2.5 & 2.3 & 2.6\end{array}$

2.6
16.5

134.9

2.7
17.1

152.0

2.8
19.1

171.1

3.0

Sources: Belizean authorities; and Fund staff estimates and projections.

$1 /$ In relation to broad money at the beginning of the period.

2/ Fiscal year beginning April 1 .

3/ Does not include debt service on publicly guaranteed debt.

4/ Exports of goods and nonfactor services.

$5 /$ Imports of goods and nonfactor services. 


\section{BELIZE: FUND RELATIONS}

(As of June 15, 2001)

\section{Membership Status}
(a) Date of membership:
March 16, 1982
(b) Status:

\section{A. Financial Relations}

II. General Department
(a) Quota:
(b) Total Fund holdings of Belize dollars:
(c) Reserve tranche position:

SDR 18.8 million SDR 14.6 million or 77.5 percent of quota SDR 4.24 million or 22.5 percent of quota

\section{Stand-By Arrangements and Special Facilities}

Stand-By Arrangement:
(i) Duration:
December 3, 1984 to June 1, 1986
(ii) Amount: SDR 7.13 million
(iii) Utilization:
SDR 7.13 million

\section{SDR Department}
(a) Net cumulative allocation:
(b) Holdings:
None
SDR 1.29 million

\section{Financial Obligations to the Fund}

Based on existing use of resources and present holding of SDRs:

None

\section{B. Nonfinancial Relations}

\section{Exchange Rate}

Since 1976, the Belize dollar has been pegged to the U.S. dollar, the intervention currency, at the rate of BZ\$2 per U.S. dollar. Since the second quarter of 1995 , the central bank has been resorting to the rationing of its sales of foreign exchange to commercial banks on an ad-hoc basis, except for some essential import items, which has given rise to restrictions on the making of payments and transfers for current international transactions. 


\section{Last Article IV Consultation}

The last Article IV consultation was concluded by the Executive Board on May 19, 2000 (EBM/00/51; the relevant documents were SM/00/83 and SM/00/84). Belize is on the standard 12-month consultation cycle.

\section{Technical Assistance}

- During November 1994-June 1995, an FAD panel expert visited Belize on four occasions to assist the authorities with the implementation of the VAT.

- In December 1995 another mission from FAD visited Belize to provide technical assistance to strengthen tax administration.

- Mr. Krysl (MAE consultant) visited Belize in February 1998 to advise the authorities on banking supervision.

- Mr. Albrecht (MAE consultant) visited Belize during March 19-30, 2001 to start a series of visits aimed at improving on-shore and off-shore banking supervision.

- Mr. Fontaine (STA) visited Belize in April 2001 to advise the authorities on balance of payments statistical issues. 


\section{BELIZE: RELATIONS WTH THE WORLD BANK GROUP \\ (As of June 5, 2001)}

\section{Financial Relations}

\section{IBRD/IDA/IFC Operations}

(In millions of U.S. dollars)

\section{IBRD loans}

Roads and Municipal Drainage

Social Investment Fund

Indigenous People Training ${ }^{1}$
Disbursed

2.1

4.5

0.0
Undisbursed

10.9

3.9

0.1

\section{Memorandum item:}

Total approved loans (including five closed loans)

Of which

Repaid to the Bank

23.4

Unpaid

42.4

IFC investments

Becol $^{2}$

4.7

Nova-Ambergris

\section{Economic and Sector Work}

A five year Country Assistance Strategy was completed for Belize in August 2000 (Report No.20708-BEL). In the CAS the Bank has identified a small program with emphasis on nonlending services. Bank projects would be small, ranging between US\$7-13 million and well focused to minimize risks. Further, the Bank will manage and mitigate these risks by monitoring, together with the IMF, the fiscal and external debt situation. Other than the ongoing US\$7 Social Investment Fund (closing date June 2002), a Roads and Drainage Project has become effective this past January. An Education Improvement Project, that includes cofinancing from UK DfID, is at an advanced stage of preparation. A second Social Investment Fund Project of US\$7 million is envisaged for FY05. Non lending services will focus on poverty updates, portfolio performance, procurement and financial management, and social safety nets. Finally, since the writing of the $2000 \mathrm{CAS}$, a powerful hurricane struck Belize. To support the reconstruction efforts, the Bank has provided US\$4.4 million in additional financing, channeling the amount through its ongoing and upcoming projects.

\footnotetext{
${ }^{1}$ Institutional Development Fund grant.

${ }^{2}$ Includes equity participation of US\$5 million.
} 


\section{BELIZE: RELATIONS WITH THE INTER-AMERICAN DEVELOPMENT BANK} (As of May 15, 2001)

\section{Current Portfolio}

(In millions of U.S. dollars)

\section{Loan}

Southern Highway

Land Administration

Environmental and Social Technical Assistance

Modernization of Agricultural Health Services

Hurricane Reconstruction and Emergency Preparedness

Tourism Development Project

Health Sector Reform Project

Hurricane Keith Emergency Reconstruction Facility

Total
Approved Undisbursed

16.0

6.9

0.9

2.6

0.1

3.6

0.2

21.3

3.5

11.0

19.8

9.8

10.4

20.0

9.8

14.2

85.2

64.9

\section{Loan Transactions}

$$
1997
$$

1998

1999

2000

\section{Net flows}

0.3

0.4

0.4

0.7

0.0

0.1

0.0

0.3
3.5

3.9

0.0

0.4
10.3

11.1

0.0

0.8

\section{Economic and Sector Work}

The country strategy paper on Belize was approved by the IDB Board in October 1999. The three-year strategy covers the agriculture, agribusiness, tourism, environment, regulatory framework (enabling environment), and social sectors, and is expected to increase significantly the Bank's exposure in Belize.

In the last three years, the IDB Board approved six large projects. In January 1998 it approved the Southern Highway Project, in July 1999 it approved the Modernization of Agricultural Services Project, in October 1999 it approved the Hurricane Reconstruction and Emergency Preparedness Projects, in June 2000 the Tourism Development Project, in October 2000 the Health Sector Reform Project, and in November 2000 the Hurricane Keith Emergency Reconstruction Project. 


\section{Belize: Relations WTH THE CARIBBEAN.DEVELOPMENT BANK}

(As of April 30, 2001)

\section{Current Portfolio}

(In millions of U.S. dollars)

\section{Loan}

Disaster Preparedness

Orange Walk Bypass

Fifth Line of Credit

Second Water and Sewerage Project

Fourth Power Project

Health Sector Reform Program

National Disaster Management (Hurricane Keith)

Enhancement of Technical and Vocational Education

Institutional Strengthening of National Training Board

Total
Approved Undisbursed

$\begin{array}{rr}8.5 & 8.4 \\ 9.5 & 9.5 \\ 7.3 & 2.5 \\ 13.8 & 8.1 \\ 13.3 & 0.6 \\ 5.6 & 5.6 \\ 0.5 & 0.5 \\ 12.7 & 12.7 \\ 0.3 & 0.3\end{array}$

71.5

II. Loan Transactions

\section{Net flows}

Gross disbursements

Amortization

Interest and charges

$\begin{array}{rrrrr}1997 & 1998 & 1999 & \mathbf{2 0 0 0} & \begin{array}{r}\text { Jan. Apr. } \\ \text { 6.6 }\end{array} \\ \mathbf{9 . 0} & \mathbf{3 . 0} & \mathbf{3 . 4} & \mathbf{- 0 . 1} \\ 10.4 & 13.6 & 9.5 & 9.0 & 2.6 \\ 2.0 & 2.1 & 3.6 & 2.3 & 1.0 \\ 1.8 & 2.5 & 2.9 & 3.3 & 1.7\end{array}$

\section{Economic and Sector Work}

The CDB Country Strategy Paper on Belize was presented to the Board in May 2000. The strategy which covers the period 2000 to 2002, proposes an allocation of US\$39.5 million to projects in tourism development, bridge construction/rehabilitation, Development Finance Corporation (DFC) Line of Credit, human resource development, and health sector reform, it also includes approximately US\$0.4 million in technical assistance. The technical assistance activities include a study on service exports expansion, family health survey, land use plan for northern Belize, restructuring of the public enterprise sector, study on health sector institutional restructuring and on the institutional capacity of the DFC, and review of education sector financing. In 2000, four new projects were approved: (i) National Disaster Management (Hurricane Keith); (ii) Institutional Strengthening of the National Training Board; (iii) Enhancement of Technical and Vocational Education; and (iv) Health Sector Reform Project. 


\section{BELIZE: STATISTICAI IsSUES}

\section{Outstanding statistical issues}

In general, the quality, coverage, and timeliness of Belize's statistical information do not permit an adequate monitoring of economic developments. There are shortcomings in national accounts, prices, external trade and debt, government finance, and labor statistics. The authorities have indicated that they would be interested in receiving technical assistance in all these areas. The Central Bank of Belize publishes a quarterly bulletin covering developments in the real, fiscal, monetary, and external sectors, as well as an annual report and a statistical digest.

\section{External debt}

There are discrepancies between the data reported by the central bank and those reported by the ministry of finance, particularly with respect to gross external disbursements to the central government. In addition, the data reported by the central bank and the ministry of finance on the external debt of the public enterprises are incomplete and inconsistent with the information provided by the public enterprises. The authorities are seeking to reduce the discrepancies and inconsistencies by fostering greater cooperation among the agencies involved.

\section{Balance of payments}

The compilation of Belize's balance of payments is based on the fifth edition of the Balance of Payments Manual (BPM5). Belize has recently completed the transition to the BPMS. In addition, the authorities are refining the process for collecting relevant data that will enable the presentation of quarterly balance of payments statistics. As for the coverage, currentness and reporting of data for publication in the International Financial Statistics (IFS) and in the Balance of Payments Statistics Yearbook (BOPSY), Belize has reported annual data on balance of payments statistics albeit with some lags. An STA mission visited Belize on April $3-6,2001$ to provide assistance on balance of payments data issues.

\section{Real sector}

With respect to the national accounts, the central statistical office does not produce GDP data by sector at market prices. The CPI market basket is based on a household expenditure survey conducted from June 1990 through March 1991 and needs to be updated, as does the reference base which currently is November 1990. Also, the CPI is calculated only four times a year (February, May, August, and November), with a lag of about three months. 


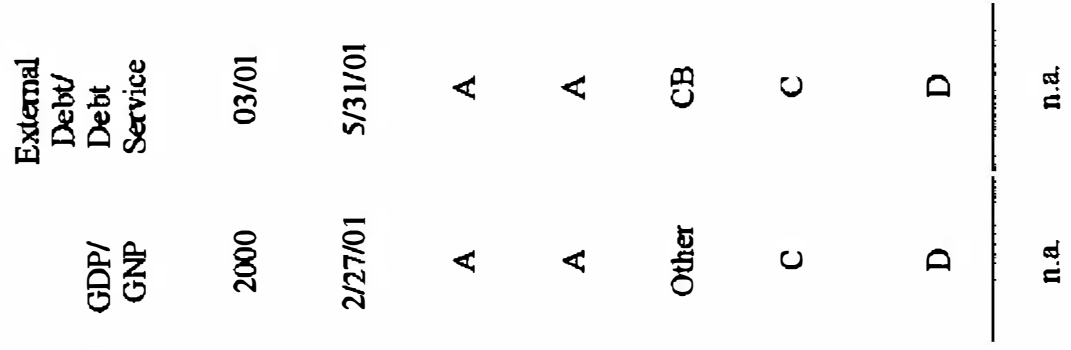

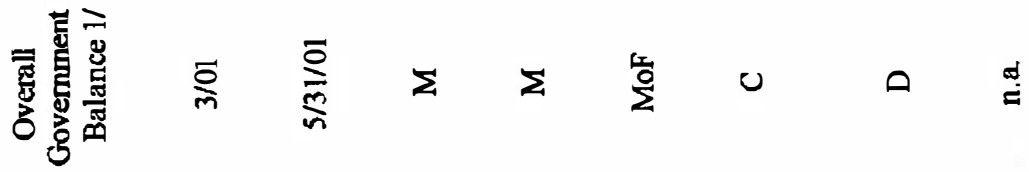

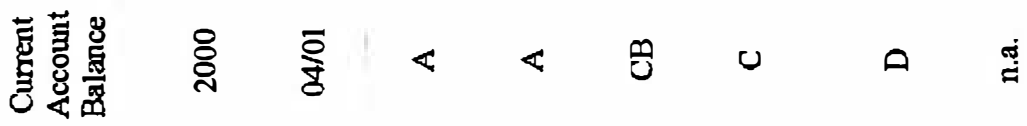

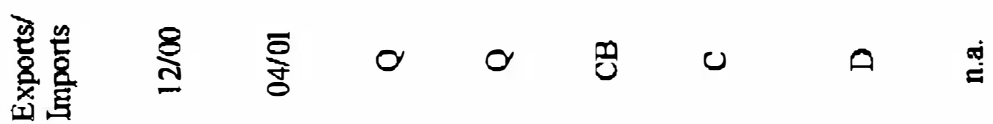

竞总希

ฮำ

.

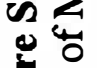

仓ั

过

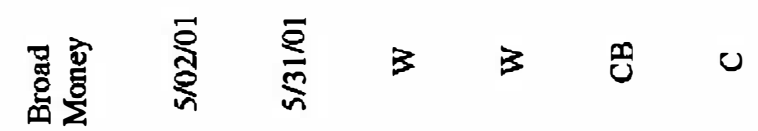

ค

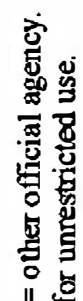



氠

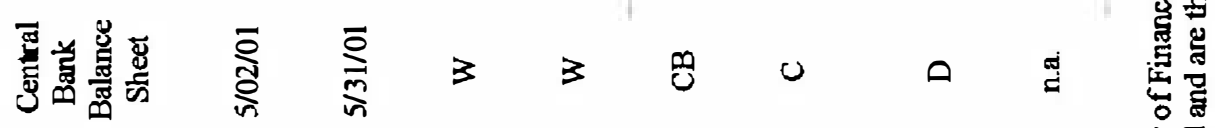

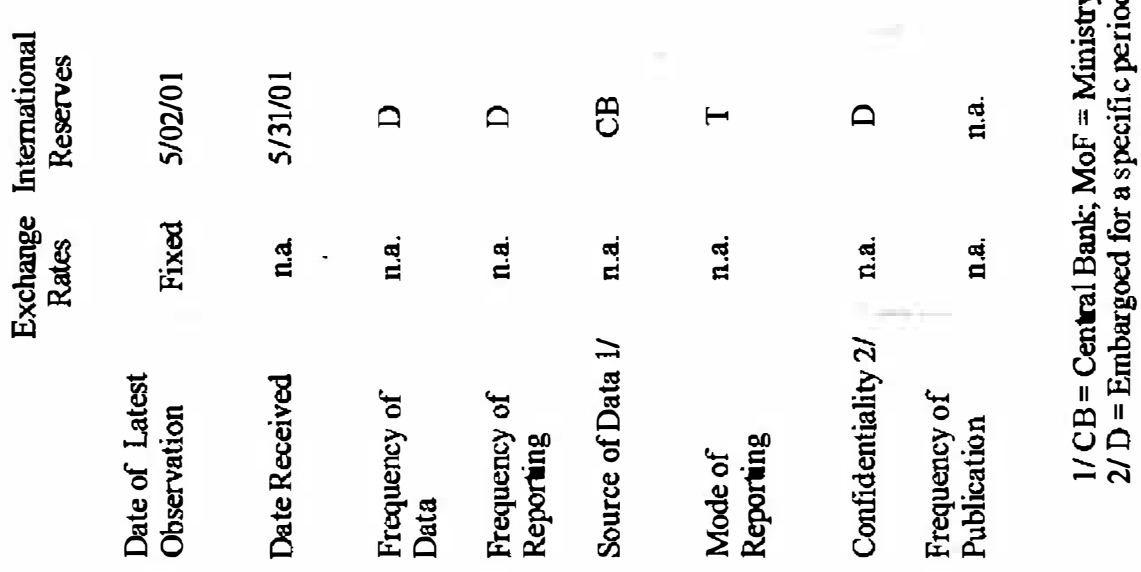




\section{INTERNATIONAL MONETARY FUND}

\section{Public Information Notice}

Public Information Notice (PIN) No. 01/81

FOR IMMEDIATE RELEASE

August 2, 2001
International Monetary Fund

$70019^{\text {th }}$ Street, NW

Washington, D. C. 20431 USA

\section{IMF Concludes 2001 Article IV Consultation with Belize}

On July 9, 2001, the Executive Board of the International Monetary Fund (IMF) concluded the Article IV consultation with Belize. ${ }^{1}$

\section{Background}

The authorities' economic policy seeks to sustain strong economic growth mainly through low taxes, large public investment, and the provision of credit to the private sector through the state-owned Development Finance Corporation (DFC). The authorities expect the resulting high rate of economic growth to generate sufficient fiscal resources to reduce the public sector deficit and service the rapidly accumulating external public debt. At the same time, they remain firmly committed to maintaining the present exchange rate peg.

Real GDP growth is estimated to have increased sharply to 10.4 percent in 2000 , while consumer prices rose by 1 percent in the absence of pressure from wages or imported prices. As a result of rapid growth in public sector investment, in part due to reconstruction efforts after hurricane Keith hit Belize in September 2000, the nonfinancial public sector deficit widened to 9.7 percent of GDP in FY 2000/01 from 8.2 percent in FY 1999/2000 (fiscal year begins April 1). The deficit was financed through privatization receipts and substantial external borrowing, mostly on commercial terms. At the same time, the DFC expanded its lending operations by 10 percent of GDP, financed also through external borrowing. As a result, the public and publicly

${ }^{1}$ Under Article IV of the IMF's Articles of Agreement, the IMF holds bilateral discussions with members, usually every year. A staff team visits the country, collects economic and financial information, and discusses with officials the country's economic developments and policies. On return to headquarters, the staff prepares a report, which forms the basis for discussion by the Executive Board. At the conclusion of the discussion, the Managing Director, as Chairman of the Board, summarizes the views of Executive Directors, and this summary is transmitted to the country's authorities. This PIN summarizes the views of the Executive Board as expressed during the July 9, 2001 Executive Board discussion based on the staff report. 
guaranteed external debt increased from 48 percent of GDP at end-1999 to 67 percent at end-2000. The expansionary fiscal stance, combined with the liquidity injection through the DFC operations, increased the liquidity overhang in the economy and created pressures in the foreign exchange market. With the rapid increase in imports resulting from public investment demand and reconstruction efforts, the current account deficit increased to 16.1 percent of GDP, which was more than financed through large capital inflows from public sector borrowing. As a result, net international reserves increased to 2.5 months of imports of goods and services.

To contain the rapid increase in external debt obligations and safeguard the exchange rate regime, Fund staff and authorities agreed on the urgent need to correct the fiscal imbalances. The government will seek to reduce the nonfinancial public sector deficit to 1 percent of GDP over a three-year period, mainly through a reduction in investment expenditure. The deficits can be financed from government deposits at the central bank and multilateral project financing with government refraining from further commercial external financing. The government also intends to review DFC operations in light of its deteriorating loan portfolio and subject it to banking sector supervision.

\section{Executive Board Assessment}

Directors noted that the Belizean economy grew rapidly in 2000 , while inflationary pressures remained low and net international reserves increased. However, they expressed concern at the continued widening of the fiscal and external current account deficits to clearly unsustainable levels, resulting in rapid increases in external public debt and debt service payments. Monetization of external loans has increased the excess liquidity in the system (as evidenced by the need to intensify rationing of foreign exchange) and created pressures in the foreign exchange markets. Directors recognized that the reconstruction efforts following hurricane Keith contributed to these developments, and that public spending was intended to develop infrastructure, diversify the economy, and meet important social objectives. Nevertheless, Directors agreed that the heightened vulnerability of the Belizean economy requires decisive corrective action.

Against this backdrop, Directors welcomed the authorities' intention to reduce the fiscal deficit to 1 percent of GDP over the next three years. This adjustment was seen as key to re-establishing sustainable fiscal and external positions, including a manageable external debt burden. During the three-year adjustment period, it would be possible for the fiscal deficits, if declining as planned, to be financed entirely through funds deposited at the central bank from a recently disbursed external commercial loan. Directors welcomed the authorities' commitment to refrain from further external bond financing, and emphasized that any further external financing on commercial terms should be avoided.

Noting past spending pressures, Directors stressed that a substantial effort will be necessary to enforce expenditure cuts of the magnitude necessary to achieve a sustainable fiscal position. They welcomed the efforts to reduce budget allocations and improve expenditure monitoring, but urged the authorities to mobilize political support for the required substantial fiscal tightening. They were of the view that the expenditure 
savings should be concentrated on scaling back domestically financed projects with relatively low rates of return, and that public sector finanicing for private housing construction should be limited to a well-targeted low-income housing program. A substantial tax revenue effort, reversing the trend of recent years, was also seen as important to achieve timely and sustained progress toward fiscal sustainability. Directors welcomed recent tax measures as a first step in this process.

Directors noted that the substantial increase in lending by the state-owned Development Finance Corporation (DFC), much of it foreign financed, has exacerbated the domestic liquidity overhang and added to the public debt burden. Loan delinquency rates are high, undermining the DFC's financial position. Directors urged the authorities to restrict DFC credit expansion and refrain from further external financing. They also cautioned that the DFC should step back from lending operations that would normally be channeled through the banking system. At the same time, they recognized the need to enhance the role of the commercial banks in providing credit. Directors welcomed the authorities' request for Fund technical assistance to review and improve management practices at the DFC, as well as their decisions to refrain from further central bank lending to the DFC and to subject the DFC to banking supervision in the course of this year.

Directors welcomed the authorities' intention to reduce excess liquidity to help secure the sustainability of the exchange rate peg. They agreed that this reduction could best be achieved through a continuous decline in net central bank credit to the public sector.

Directors noted that the central bank's capacity to supervise commercial banks needs strengthening and welcomed the authorities' interest in receiving further technical assistance from the Fund in this respect. They recommended that legislation be enacted to give the central bank supervisory authority over credit unions, other nonbank financial intermediaries, and the offshore financial sector.

Directors welcomed the reduction in the maximum external tariff rate from 25 percent to 20 percent, and recommended that remaining quantitative import restrictions be converted into tariffs. They also advised the authorities to consider the elimination of ad hoc duty exemptions, which would improve transparency and resource allocation.

Directors regretted that there is no clear timetable for phasing out the ad hoc rationing of foreign currency sales by the central bank, which constitutes an exchange restriction subject to Fund approval under Article VIII.

Directors were concerned about the quality of Belize's statistical information and welcomed ongoing technical assistance to improve the quality of economic statistics, particularly in the areas of balance of payments and national accounts. 
Public Information Notices (PINs) are issued, (i) at the request of a member country, following the conclusion of the Article IV consultation for countries seeking to make known the views of the IMF to the public. This action is intended to strengthen IMF surveillance over the economic policies of member countries by increasing the transparency of the IMF's assessment of these policies; and (ii) following policy discussions in the Executive Board at the decision of the Board. 
Belize: Selected Economic Indicators

$\begin{array}{lllll}1997 & 1998 & 1999 & 2000 & 2001\end{array}$

(Annual percentage change, unless othenwise specified)

National income and prices

GDP at factor cost, constant prices

Consumer prices (end of period)

$3.2 \quad 1.5$

$6.5 \quad 10.4$

5.0

Real effective exchange rate 1 /

$-0.6$

$-0.8$

$-1.1$

1.0

$-0.3 \quad 3.8$

\section{Money and credit}

Credit to the public sector

Credit to the private sector

2.0

5.1

$-1.8$

$-5.4$

4.3

Money and quasi-money (M2) $2 /$

$\begin{array}{rrr}10.5 & 9.6 & 7.9\end{array}$

5.7

3.3

7.3

6.4

10.8

12.9

(In percent of GDP)

Nonfinancial public sector $3 /$

Current savings

Capital expenditure

Overall balance

4.6

2.8

3.5

11.9

13.1

13.0

15.5

$-4.2$

$-6.0$

$-8.2$

$-9.7$

$-5.7$

External sector

Extemal current account 4/

Public external debt (end of period) $5 /$

$\begin{array}{rrrrr}-3.5 & -6.2 & -9.0 & -16.1 & -12.3 \\ 37.2 & 38.6 & 48.3 & 67.4 & 68.2\end{array}$

(In percent of exports of goods and services)

Debt 5

Debt service 6/

$\begin{array}{rr}70.7 & 76.4 \\ 9.1 & 9.8\end{array}$

95.9

143.7

126.8

$\begin{array}{llll}9.1 & 9.8 & 9.6 & 10.5\end{array}$

13.1

Sources: Belize authorities; and Fund staff estimates and projections.

1/ End of period; depreciation (-).

$2 /$ In relation to liabilities to the private sector at the beginning of the period.

3/ Fiscal year starts on April 1.

4/ Including official grants.

5t Public and publicly guaranteed external debt.

6/ Public external debt. 


\section{Statement by Thomas A. Bernes, Executive Director for Belize July 9, 2001}

On behalf of my Belizean authorities, I would like to thank staff for yet another useful and constructive Article IV consultation. The opportunity to discuss economic developments and policies in Belize has been - as usual - of great value to the authorities and will provide useful input into ongoing policy discussions.

On the surface, the Belizean authorities' economic strategy may seem to entail a number of risks, particularly with respect to external indebtedness and the sustainability of fiscal policy. Staff have been characteristically good in identifying possible problems and vulnerabilities arising from the authorities' efforts to stimulate growth. But as is often the case, the devil is in the detail, and after taking into account a number of additional considerations and "one-off" factors, I believe the situation is far more nuanced than appears in the staff report.

Without question, the authorities face a number of major challenges, some of which are directly linked to the impact of Hurricane Keith last fall and others which are more typical of those facing many small developing economies in adapting to a constantly evolving and increasingly globalized world. The authorities believe that staff have assessed their policy stance predominantly from the latter standpoint, that is, from a generic, but well founded, approach to economic management in a small developing economy. What would give a more accurate assessment of Belizean economic prospects is a heightened appreciation of the former - that is, how hurricane reconstruction has affected the recommended policy paradigm in the short term. Hurricane Keith, which hit Belize in September/October 2000, severely damaged tourist facilities, sugar cane and rice fields and caused extensive damage to roads and bridges. In the face of this, the speed at which the authorities sought to re-establish the productive infrastructure of the economy was critical for the restoration of economic activity and social stability. It can therefore be argued that the authorities development strategy over the past year is consistent with sound economic management, particularly after taking into account efforts to contain the risks inherent in the reconstruction and recovery strategy.

Without question, the pace of external borrowing, public spending, and the current account deficit are not sustainable. But they were not intended to be sustained. Rather, economic policies need to be looked at from a longer-term perspective. Efforts during the last year were intended to restore productive infrastructure and housing to get the economy back on its feet as a prelude to a retraction of the Government's presence in the economy. The large current account deficit must also be viewed from a multi-year perspective, given the dampening effect on exports and tourism due to the hurricane and the significant import content of reconstruction efforts.

Staff have expressed concern with the size of the non-financial public-sector debt which, admittedly, is large. However, it should be noted, that the central government's share 
of this amounts to around 38.7 percent of GDP. More importantly, spending must be viewed against the backdrop of the September/October 2000 hurricane, which led to reconstruction expenditure of around 3 percent of GDP. As staff note, this deficit was financed through substantial privatization receipts (3.2 percent of GDP), external borrowing, and - to a smaller degree - concesssional borrowing from regional development banks and Taiwan.

Accommodation was also made for hurricane-related spending through a contraction of current spending from 20.6 percent of GDP to 18.9 percent of GDP. Looking ahead, additional revenue measures have been introduced to assist in the fiscal consolidation effort, including the introduction of a 1.25 percent "Social Fee" on all transactions in the fast growing "Free Zone", 5 percent import surcharge on goods containing plastic, and a 5 percent "Land Speculation Tax" on undeveloped land. The authorities have also established offices of a Revenue Commissioner, Contractor General and Ombudsman to enhance efficiency, transparency and accountability in public spending and revenue collection.

The size of the deficit has led staff to express concem with the level of external borrowing. In assessing the extent to which this has enhanced the external vulnerability of the economy, it should be noted that of the 67 percent of GDP in total public and publiclyguaranteed debt at the end of 2000 , some 16 percentage points was publicly-guaranteed debt which included obligations arising from securitization operations, to which dedicated streams of income are attached. Insurance receipts also helped finance imports of building materials. Some $\$ 50$ million or $6 \frac{1}{4}$ percent of GDP was held on deposit at the end of 2000 . Taken together, the implied vulnerability of the debt burden is significantly diminished.

Much of the reconstruction effort is being channeled through the Development Finance Corporation (DFC), whose lending expanded at a rapid pace over the past year. Activities that are being financed by DFC include low-income housing and the restoration of basic infrastructure, which staff agree has had a positive impact on Belize's competitiveness. It is questionable that many of the activities that DFC has helped finance over the past year would have received reasonably-priced financing from commercial banks. Indeed, in the context of the 2000 Article IV consultation, staff expressed concern with a lack of competition in the domestic banking sector. Add to this the typical risk aversion of commercial banks to extend credit to small and medium sized enterprises, and you have a private-sector banking system that was not in a position to respond rapidly to the posthurricane reconstnuction needs. This should be kept in mind in assessing the validity of staff"s concerns that the expansion of DFC operations might create "distortions in the pricing of risk in the credit markets".

As noted, much of the lending to date was for low-income housing. This is not generally considered to be "productive" investment. However, in an economy whose future economic prospects depend critically on the health of the tourism sector, poverty-reducing and socially-stabilizing investment in housing is productive in that it helps reduce unemployment and prevent social unrest, both disincentives to tourist visits. It should also be noted that a significant portion of the residential lending was undertaken in an effort to provide adequate housing for the large number of Hondurans and Guatemalans fleeing natural disasters in their countries. 
Looking forward, it is the authorities' intention to retract the public sector from the operations of DFC as part of a broader policy of fiscal consolidation. A first step in this direction is the spinning off of the medium and high-quality end of the DFC portfolio while retaining the more concessionary support (which would not be of interest to the private sector) within the public sector. Staff note that these financial assets were not sold but rather used as collateral, thereby leaving the risks with the DFC. The importance of this should not be overstated since, as noted, the securitization of DFC loans involved the medium and high quality end of the DFC portfolio. Moreover, sinking funds, designed to facilitate an increase in value through the capitalization of interest, have been created to cover the entire bullet payment at maturity.

It is also important to acknowledge the significant success Belize has had in diversifying its economy in response to changing external market and trade regime developments. As staff point out, the role of infrastructure investment by the public sector has been key in this regard. Like a number of other Caribbean countries, Belize faces the erosion of EU agricultural preferences in the period ahead. In response, and in addition to facilitating an upgrading of its tourist infrastructure, the Belizean private sector is very active in a number of high growth industries, including shrimp farming and eco-tourism.

Staff are correct in pointing to a number of shortcomings in the management of DFC, and for this, the authorities are appreciative. In order to improve the accounting and transparency of DFC's operations, the Caribbean Development Bank (CDB) recently conducted an audit of DFC's accounts. The field work was completed last month and the authorities are awaiting the results and recommendations from the CDB on how to better manage DFC's activities. Moreover, acknowledging the legitimacy of staff's concern with the level of non-performing loans in DFC's portfolio, the authorities are in the process of strengthening the loan recovery capacity of DFC. To this end, DFC collection activities are being consolidated in a special collections unit. The authorities have indicated their intention, in the course of 2001, to subject DFC to the same prudential noms and regulatory oversight as the banking sector. They are in the process of seeking counterpart financing from a multilateral agency or bilateral donor to bolster staffing of the central bank's supervisory department and will also be receiving technical assistance from the Fund.

It should be pointed out that the NPL ratio reported in the staff paper is unambiguously overstated due to a shortcoming in DFC's accounting software. Footnote 9 on page 7 of the staff report should therefore read that "non-performing loans are somewhat overstated due to software and management practices in use at the DFC". Staff have suggested that new credit operations of the DFC were "likely to further undermine the solvency of the DFC". With the bulk of post-hurricane residential reconstruction largely addressed, the DFC in the period ahead will be able to focus more of its efforts on the productive export sector suggesting that - to the extent that one can make any predictions about the impact of future credit operations -DFC's solvency is likely to be strengthened and foreign exchange earnings will be boosted. 
Lastly, while developments in the international economy over the past few years have rightly drawn attention to the risks involved in fixed exchange rate regimes, staff's concern with an erosion in the credibility of the exchange rate peg is somewhat overstated. Indeed, the evidence suggesting that the foreign exchange queue has increased and the parallel market spread has increased is largely anecdotal and not as conclusive as suggested in the staff report. To the extent that a spread in the parallel market exists, it has been relatively stable and can be explained by taxes and commissions charged in the official market. 